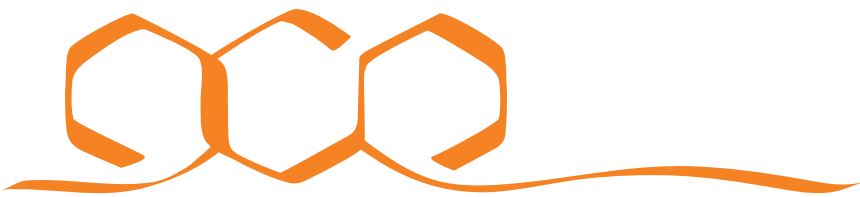 COMMUNICATIONS CHEMISTRY
}

REVIEW ARTICLE

https://doi.org/10.1038/s42004-019-0160-1

\section{Synthesis of corannulene-based nanographenes}

\author{
Ezzah M. Muzammil1,2, Dzeneta Halilovic ${ }^{1,2} \&$ Mihaiela C. Stuparu (iD ${ }^{1}$
}

Corannulene $\left(\mathrm{C}_{20} \mathrm{H}_{10}\right)$ is a polycyclic hydrocarbon in which five six-membered rings surround a central five-membered ring to construct a bowl-like aromatic structure. Here we examine the development of synthetic strategies that allow for the growth of the peripheral aromatic rings as a means to extend the aromatic area of the central corannulene nucleus and provide access to unique nanocarbon molecules.

\begin{abstract}
$p^{2}$-hybridised structures of carbon have fascinated the research community for a very long time. In 1985, buckminsterfullerene, otherwise known as $\mathrm{C}_{60}$, was discovered (Fig. 1a) ${ }^{1}$. In this ball-shaped molecule, the curvature in the structure stems from the presence of fivemembered rings. In 1991, carbon nanotubes arrived on the scene ${ }^{2}$. Here, the structure is cylindrical and composed of only rolled-up six-membered rings. In 2004, a sheet-like single layer from graphite-graphene-was isolated ${ }^{3}$. All of these materials were shown to have extraordinary electronic and mechanical properties due to their unique curved or planar $s p^{2}$-hybridised aromatic structures.

Inspired by these discoveries, chemists have been developing strategies to access such aromatic hydrocarbons through rational ('bottom-up') synthetic approaches. Scott's 12-step chemical synthesis of fullerene $\mathrm{C}_{60}$ from a rationally designed precursor is a testament to the ingenuity and resourcefulness of organic chemists ${ }^{4}$. In planar structures, nanographenes (well-defined cutouts of graphene with nano-scale dimensions) can now be prepared on a regular basis with a very diverse portfolio ${ }^{5}$. It is expected that combining the planar structure of graphene with the curvature of fullerenes may produce hybrid materials with interesting properties ${ }^{6-8}$.

To induce non-planarity into nanographenes, a practical approach would be to introduce a fivemembered ring such as in the case of fullerene, $\mathrm{C}_{60}$. A perfect building block that allows for such a structural arrangement to happen is corannulene (1)-a molecule in which five six-membered rings surround a central five-membered ring to give a bowl-like structure (Fig. 1b) ${ }^{9-20}$. Corannulene also offers many beneficial features as a molecular building block. It has high solubility in common organic solvents. It can be derivatized in a well-defined manner. Due to synthetic ease, the derivatives can be prepared on a multigram scale. These attributes are important as they allow for the scalable preparation of carefully designed corannulene-based building blocks and the subsequent synthesis, purification and structural analysis of the larger (fused) aromatic systems.

Recently, therefore, there has been a surge in employment of corannulene as a core molecule in the synthesis of extended aromatic structures. Our aim in this review article is to discuss
\end{abstract}

\footnotetext{
${ }^{1}$ Division of Chemistry and Biological Chemistry, School of Physical and Mathematical Sciences, and School of Materials Science and Engineering, Nanyang Technological University, 21 Nanyang Link, 637371 Singapore, Singapore. ${ }^{2}$ These authors contributed equally: Ezzah M Muzammil, Dzenta Halilovic.

Correspondence and requests for materials should be addressed to M.C.S. (email: mstuparu@ntu.edu.sg)
} 
a

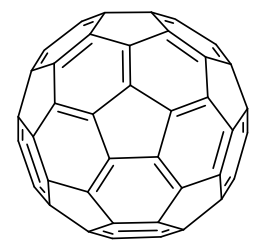

$\mathbf{C}_{60}$

b

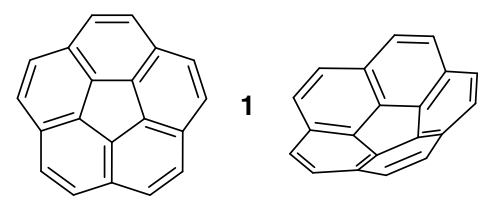

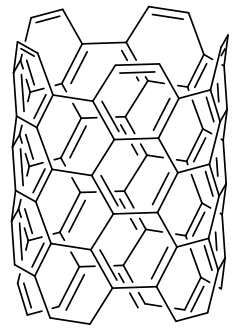

Carbon nanotube

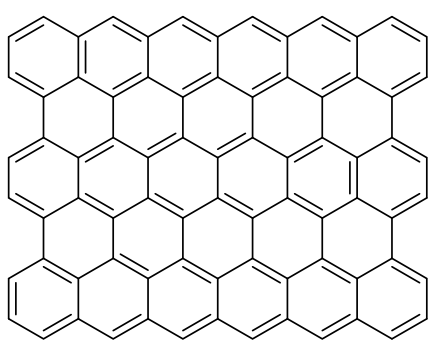

Graphene
C<smiles>Clc1cc2c(Cl)cc3c(Cl)cc4c(Cl)cc5c(Cl)cc1c1c5c4c3c21</smiles>

$\downarrow$

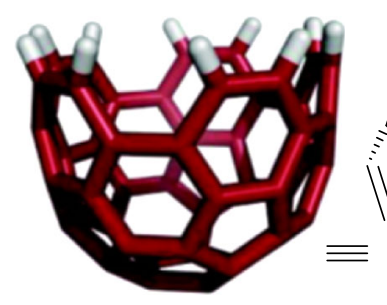

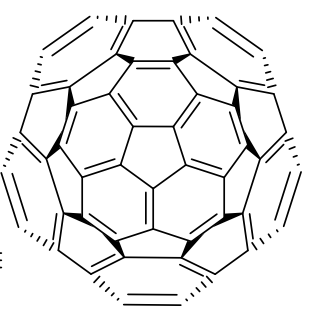

4<smiles>CC(C)(C)C</smiles>

Fig. 1 Curved and planar polycyclic aromatic hydrocarbons. a Chemical structures of fullerene, carbon nanotube and graphene. b Chemical structure of corannulene 1. c Synthesis of carbon nanotube end-cap. (i) $\mathrm{C}_{38} \mathrm{H}_{53} \mathrm{CINO}_{2} \mathrm{PPd} \cdot \mathrm{CH}_{3} \mathrm{OC}_{4} \mathrm{H}_{9}, 2,6$-dichlorophenyl zinc chloride, $\mathrm{THF}, 100{ }^{\circ} \mathrm{C}, 5 \mathrm{~h}$; $52 \%$. (ii) Flash vacuum pyrolysis, $1100{ }^{\circ} \mathrm{C}, 0.25$ Torr; $3 \%$. c is partially reprinted with permission from ref. ${ }^{23}$. Copyright 2012 American Chemical Society

recent advances in this fascinating area of research. In light of the two comprehensive review articles written by the pioneers of the field, Scott $^{9}$ and Siegel ${ }^{10}$, we limit our discussion to examples published after 2006. The discussion is categorised on the basis of synthetic method and a chronological order is maintained in each section.

\section{Pyrolytic method}

Barth and Lawton's first synthesis of corannulene was a true feat of organic synthesis. It comprised 17 synthetic steps and allowed access to this beautiful molecule in a $<1 \%$ overall yield ${ }^{21}$. Following this elegant work, the field remained dormant for the next quarter of a century until Scott's group demonstrated flash vacuum pyrolysis (FVP) as an alternative to Barth and Lawton's solution-phase method. Scott's method allowed access to corannulene in a remarkably practical fashion (3-step synthesis with an overall yield of $26 \%)^{22}$. This work breathed new life into the research area of non-planar aromatics and rejuvenated the field of corannulene.

In FVP, high temperatures are employed to overcome the energy barrier of introducing the necessary strain onto the molecular structure. Conversion of the precursor to the desired product depends on both the heating time and temperature. The power of this synthetic tool can be appreciated in the final synthetic step of a hemispherical polyarene $\left(\mathrm{C}_{50} \mathrm{H}_{10}\right)$ that could serve as a carbon nanotube end-cap (Fig. 1c) ${ }^{23}$. The first step of the synthesis is a five-fold chlorination of corannulene with iodine monochloride. The pentachloro product 2 follows a Negishi coupling with 2,6-dichlorophenylzinc chloride to present precursor 3. The $\mathrm{C}-\mathrm{Cl}$ bonds are cleaved during the pyrolysis of $\mathbf{3}$ to generate aryl radicals that join to form a web of five-membered rings in polyarene 4 . X-ray analysis of crystals of 4 confirm the structure and measure a bowl depth of $5.16 \AA$. $\mathrm{A} \mathrm{CS}_{2}$ molecule was read in the crystal structure in the 'basket' of the polyarenea sulfur atom hovering above the centre of the structure and the carbon atom hovering below the plane of the rim carbons. This work demonstrates that the FVP method originally developed for the preparation of corannulene and fullerene $\mathrm{C}_{60}$ is still relevant and can be a valuable synthetic tool in the preparation of carbonbased nano-tubular architectures through rational synthesis pathways. The reader is referred to a recent conference paper by Scott for an insightful discussion on this approach to carbon nanotubes and its prospects for the future ${ }^{24}$.

While FVP has been critical in rejuvenating the field, the high temperatures limit the range of functionalities on the corannulene scaffold. Solution-phase methods alleviate this situation by employing milder reaction conditions. In this regard, the reactions may be aided by metal catalysis. Alternatively, metal-free conditions can be employed to achieve the same purpose. In the following sections, we examine both pathways for the extension of the corannulene nucleus.

\section{Reactions involving metal catalysis}

Pd-catalysed coupling. Scott's group in 2007 reported the synthesis of extended corannulene structures; pentaindenocorannulene 
a<smiles>Clc1cc2c(Cl)cc3c(Cl)cc4c(Cl)cc5c(Cl)cc1c1c5c4c3c21</smiles>

2

b<smiles></smiles><smiles>Clc1ccccc1-c1cc2c(-c3ccccc3Cl)cc3c(-c4ccccc4Cl)cc4c(-c5ccccc5Cl)cc5c(-c6ccccc6Cl)cc1c1c5c4c3c21</smiles>

5

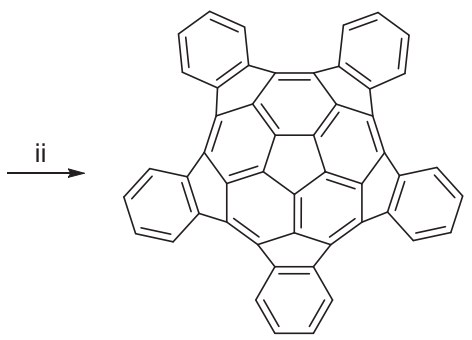

7<smiles>c1ccc2c(c1)Cc1ccc3ccc4ccc5ccc6ccc1c1c-2c3c4c5c61</smiles>

10<smiles>c1ccc2c(c1)Cc1ccc3ccc4ccc5ccc6ccccc6c5c4c3c1-2</smiles>

11<smiles>CC(C)COc1ccccc1Cl</smiles><smiles>[B]c1ccc2c(-c3ccccc3Cl)c(-c3ccccc3Cl)c(C=C)c(Cc3ccccc3)c2c1</smiles>

12

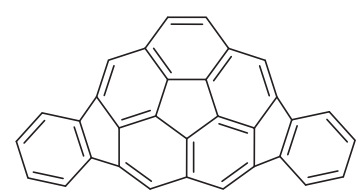

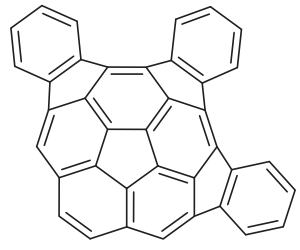

13

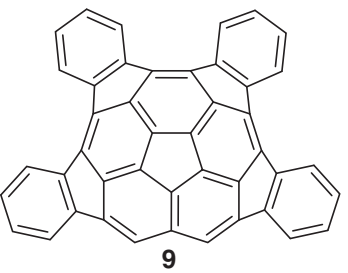

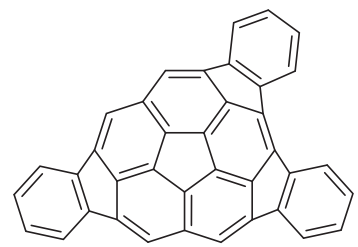

14

d<smiles>CCc1cccc2cccc(C#C[Al]C(C)(C)C)c12</smiles>

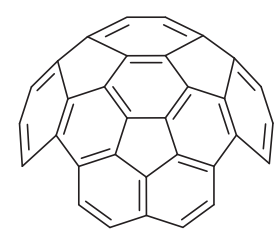

15

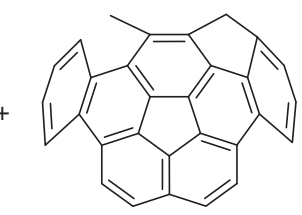

17

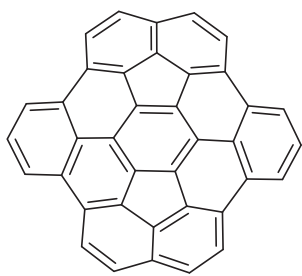

18 e<smiles>CCCOc1c(S(C)(=O)=O)c2ccc3ccc4ccc5ccc1c1c5c4c3c21</smiles><smiles>c1cc2ccc3ccc4ccc5ccc1c1c2c3c4c51</smiles>

$\downarrow i$

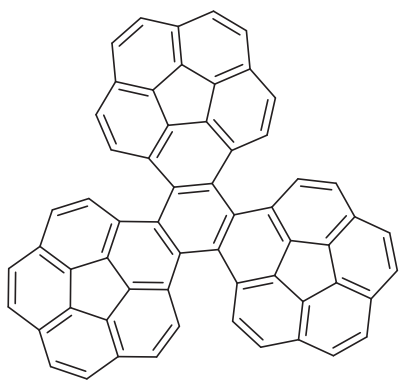

20

Fig. 2 Corannulene extension pathways involving palladium catalysis. a Synthesis of pentaindenocorannulene. (i) $\mathrm{Pd}_{2}(\mathrm{dba})_{3}, 1,3-b i s(2,6-\mathrm{diisop}$ ropylphenyl) imidazolium chloride, $\mathrm{Cs}_{2} \mathrm{CO}_{3}$, dioxane, $80^{\circ} \mathrm{C}$, $48 \mathrm{~h}$; 48\%. (ii) $\mathrm{Pd}\left(\mathrm{PCy}_{3}\right)_{2} \mathrm{Cl}_{2}, \mathrm{DBU}, \mathrm{DMAc}, 180^{\circ} \mathrm{C}$ (microwave), $45 \mathrm{~min} ; 35 \%$. b Synthesis of tetraindenocorannulene. (i) $\mathrm{Pd}\left(\mathrm{PPh}_{3}\right)_{4}, \mathrm{~K}_{2} \mathrm{CO}_{3}$, toluene/EtOH/ $\mathrm{H}_{2} \mathrm{O}, 85^{\circ} \mathrm{C}, 24 \mathrm{~h} ; 91 \%$. (ii) $\mathrm{Pd}(\mathrm{PCy})_{2} \mathrm{Cl}_{2}, \mathrm{DBU}, \mathrm{DMAc}, 170{ }^{\circ} \mathrm{C}$ (microwave), 40 min; $13 \%$. c Mono, di, and triindenocorannulenes prepared by palladium-catalysed coupling reaction. d Wu's synthesis of buckybowls 15-18. (i) $\mathrm{Pd}(\mathrm{OAc})_{2}, \mathrm{C}_{6} \mathrm{H}_{5} \mathrm{l}$, AgOAc, $p$-xylene, $110{ }^{\circ} \mathrm{C}, 36 \mathrm{~h} ; 60 \%\left(\mathrm{Ar}=2,6-\mathrm{C}_{6} \mathrm{H}_{3} \mathrm{Cl}_{2}\right)$. (ii) $\mathrm{Pd}\left(\mathrm{PC}_{3}\right)_{2} \mathrm{Cl}_{2}, \mathrm{DBU}, \mathrm{DMF}, 160{ }^{\circ} \mathrm{C}, 36 \mathrm{~h} ; 31 \%$. (iii) 2-butyne, $\mathrm{Rh}(\mathrm{PPh})_{3} \mathrm{Cl}, \mathrm{p}$-xylene, $110{ }^{\circ} \mathrm{C}, 60$ h; 99\%. (iv) $\mathrm{Pd}\left(\mathrm{PCy}_{3}\right)_{2} \mathrm{Cl}_{2}, \mathrm{DBU}, \mathrm{NMP}, 160{ }^{\circ} \mathrm{C}, 36 \mathrm{~h} ; 28 \%$ (16:17, 71:29). (v) RhCl $\left(\mathrm{PPh}_{3}\right)_{3}, \mathrm{DDQ} ; 90 \%$. (vi) $\mathrm{Pd}\left(\mathrm{PCy}_{3}\right)_{2} \mathrm{Cl}_{2}, \mathrm{DBU}_{;}>10 \%$. e Corannulene trimer synthesis. (i) $\mathrm{Pd}_{2}(\mathrm{dba})_{3}, \mathrm{CsF}, \mathrm{MeCN}, \mathrm{rt}, 12 \mathrm{~h} ; 40 \%$ 
and tetraindenocorannulene (Fig. 2a) ${ }^{25}$. The synthesis of the former starts with a Suzuki-Miyaura coupling of penta-chlorinated 2 with 2-chlorophenyl-boronic acid to give $\mathbf{5}$ which undergoes $\mathrm{Pd}$ catalysed intramolecular arylation assisted with microwave heating for the conversion to $\mathbf{6}$. A similar pathway is used to afford 9 with the difference being the starting material. As for 9, starting point tetrabromocorannulene 7 undergoes the Suzuki-Miyaura coupling to form $\mathbf{8}$ where the same Pd-catalysed conditions are used (including microwave heating) to achieve tetraindenoannulated 9 (Fig. 2b). Both polyindenoannulated corannulenes show multiple peaks in the UV-Vis spectra with absorption tails in the visible region. A pyrolysis route was explored and tetraindenocorannulene was formed with low yields of $1.3 \%$ and no amount of pentaindenocorannulene could be isolated. In these indenocorannulene structures the carbon atoms at the core of corannulene experience greater pyramidalisation than $\mathrm{C}_{60}$ as a result of connecting the peri carbons of corannulene as per the POAV analysis of the crystal structures of $\mathbf{6}$ and $\mathbf{9 .}$

The class of indenocorannulenes established by Scott was expanded to a total of seven members by Scott's group in 2009 by reporting the palladium-catalysed synthesis of 5 more indenoannulated corannulenes: 10, 11, 12, 13 and 14 (Fig. 2c) ${ }^{26}$. A general route follows as (1) Suzuki-Miyaura coupling of polyhalogenated corannulene with 2-chlorophenyl-boronic acid and; (2) subsequent intramolecular cyclisation to stitch one or more 5membered rings in a palladium-catalysed reaction subjected to microwave heating. ${ }^{1} \mathrm{H},{ }^{13} \mathrm{C}$ NMR and UV-VIS spectroscopic studies were performed on all seven indenocorannulenes and $\mathrm{X}$ ray analysis of the crystals were carried out with POAV analysis of Hadon to quantify the pyramidalisation angles.

Wu's group in 2011 reported a palladium-catalysed synthesis of buckybowls 15, 16 and 17 (Fig. 2d) ${ }^{27}$. The synthesis of 15 starts from a cycloaddition of 1,8-bis(aryl-ethynyl)naphthalene and iodobenzene to give a tetrachloro compound where a quadruple ring-closure is assisted with catalyst $\mathrm{Pd}\left(\mathrm{PCy}_{3}\right) \mathrm{Cl}_{2}$ in the presence of DBU to afford 15. The same starting material is cocyclotrimerised with 2-butyne followed by being subjected to the same palladium catalysis to give a mixture of products 16 and 17. Later, the authors utilized a similar strategy to obtain $\mathbf{1 8}$ using acenaphthalene as a reactant, an aromatization step, and a palladium-catalysed ring-closing sequence ${ }^{28}$. The solubility of 18 was found to be low in common organic solvents. X-ray crystallography analysis showed that the bowl was deep (ca. $2.30 \AA$ ). In terms of the molecular structure, 18 represent a subunit of $\mathrm{C}_{70}$ and higher fullerenes.

A palladium-catalysed cyclotrimerization of corannulyne 19 to furnish hydrocarbon $\mathrm{C}_{60} \mathrm{H}_{24}$ (20) was reported by Sygula's group in 2011 (Fig. 2e) ${ }^{29}$. Aryne $\mathbf{1 9}$ was generated from 2trimethylsilylcorannulenyl triflate that can cyclotrimerise to $\mathbf{2 0}$ in the presence of catalyst $\operatorname{Pd}_{2}(\mathrm{dba})_{3}$. The presence of the three bulky corannulene moieties bound to an axis of a benzene ring produces substantial steric hindrance forcing $\mathbf{2 0}$ to assume a propeller-like twisted structure. The most stable conformation is that of an 'up-up, down-down, up-down' structure as observed in its crystal structure. The conformational conversion was studied with variable temperature NMR spectroscopy of $\mathbf{2 0}$ which reveal a high activation barrier as the signals of the protons are broadened at $140{ }^{\circ} \mathrm{C}$ and sharpened at $0{ }^{\circ} \mathrm{C}$. The bowl inversion studies show that the corannulenes are distinct from one another in terms of bowl inversion as a result of their unsymmetrical environments.

Itami and Scott in 2013 reported the synthesis of warped nanographenes ${ }^{30}$ 25/26 which begins from a corannulene core that expands with aromatic six-membered rings and sevenmembered ring webbings in between (Fig. 3). Three different routes to expand the molecule were outlined. One of the methods is a complete $\mathrm{C}-\mathrm{H}$ phenylation of all the hydrogens on corannulene $(21)$ in the presence of catalyst $\mathrm{Pd}(\mathrm{OAc})_{2}$. The second is a five-fold $\mathrm{C}-\mathrm{H}$ biphenylation (22) with the same catalyst and the last, corannulene undergoes a five-fold $\mathrm{C}-\mathrm{H}$ borylation (23) that proceeds into a Suzuki-Miyaura coupling $(\mathbf{2 4})^{31}$. These extended corannulene structures can undergo cyclodehydrogenation to form carbon-rich warped nanographenes. The crystal of the nanographene endows a negative curvature geometry to the lattice due to the introduction of oddnumbered ring defects. $\mathbf{2 6}$ has a double concave structure due to the $\mathrm{C}-\mathrm{C}-\mathrm{C}$ bonds moving away from the natural angle of $120^{\circ}$ to angles of within a range of $106^{\circ}$ to $138^{\circ} .25$ and 26 are soluble in several organic solvents-a distinct difference from graphitebecause of the absence of large-area van der Waal's interactions between its adjacent molecules. The absorption spectra show the longest maximum wavelength of 26 to be at $418 \mathrm{~nm}$ and its fluorescence at $504 \mathrm{~nm}$ and $535 \mathrm{~nm}$ with a quantum yield of 0.26 . Cyclic voltammetry measurements of 25 present two reversible oxidation at oxidation potentials $+0.63 \mathrm{~V}$ and $+0.97 \mathrm{~V}$ versus the ferrocene/ferrocenium couple $\left(\mathrm{Fc} / \mathrm{Fc}^{+}\right)$for the first and second potentials, respectively.

Along similar lines, Segawa and Itami demonstrated preparation of the first example of a fused five-helicene system $\mathbf{2 8}$ where each helicene comprises six repeating units (Fig. 3). The synthesis employs selective reactivity of aryl bromides over aryl chlorides to first achieve C-Br coupling through Suzuki-Miyaura reaction on pentaborylcorannulene scaffold to access chlorinated 27 which upon direct arylation conditions, again under palladium catalysis, generates $28^{32}$. 28 is different from 25 and $\mathbf{2 6}$ as the phenanthrene units are separate from each other and forms a unique $\pi$-system with a propeller-like structure with regular twists and turns throughout the molecule. Very recently the authors extended their elegant work by incorporating thiophene heterocycles into the warped nanographene structure ${ }^{33}$.

Dibenzocorannulene-fused porphyrin was reported by Osuka as one of the few large hybrid planar-non-planar aromatic structures (Fig. 4a) ${ }^{34}$. The synthesis begins from a cross-coupling of brominated porphyrin 29 with corannulene-containing 30 giving linked product 31. A $\beta$-brominated porphyrin 32 was cross-coupled with 30 producing a $\beta$-linked corannulene on porphyrin 33. Both 31 and 33 were subjected to oxidation with $\mathrm{FeCl}_{3}$ to form five-membered fused ring in $\mathbf{3 4}$ and six-membered fused ring 35 thus extending the $\pi$-conjugation between porphyrin and corannulene. The dibenzocorannulene bowl depths in 34 and 35 are found to be $0.71 \AA$ and $0.83 \AA$, respectively.

Cao et al. reported a method to extend the $\pi$-conjugation of corannulene with heterocyclic thiophenes by first coupling four thiophene fragments followed by an oxidative cyclisation to bridge the attached aromatic systems (Fig. $4 \mathrm{~b})^{35}$. Initially, tetrabromocorannulene 7 is linked with thiophenes 2-(tributylstannyl)-5-hexylthiophene 36 and 3-(tributylstannyl)-5-hexylthiophene 37 with a Stille coupling catalysed by $\mathrm{Pd}\left(\mathrm{PPh}_{3}\right)_{2} \mathrm{Cl}_{2}$. The coupled products $\mathbf{3 8}$ and $\mathbf{3 9}$ are then cyclised oxidatively with DDQ and $\mathrm{FeCl}_{3}$ respectively to afford fused isomers $\mathbf{4 0}$ and 41. The products exhibit exceptional thermal stability where decomposition occurs at $447^{\circ} \mathrm{C}$ for 40 and $452{ }^{\circ} \mathrm{C}$ for 41 . Incorporating thiophene units to corannulene can improve the charge transport properties (for instance hole mobility of 0.06 $\mathrm{cm}^{2} \mathrm{~V}^{-1} \mathrm{~s}^{-1}$ ) and its arrangement making it a suitable candidate for applications in organic field-effect transistors (OFETs).

A one-pot, two-step synthesis of methylene-bridged arenes was reported by $\mathrm{Wu}$ in 2015 (Fig. $4 \mathrm{c})^{36}$. Among the arenes used was corannulene. Specifically, bromocorannulene $\mathbf{4 2}$ is cross-coupled with alkyne $\mathbf{4 3}$ following a base-facilitated retro Diels-Alder condensation that arrives at $\mathbf{4 4}$. Crystal structure of 44 was 

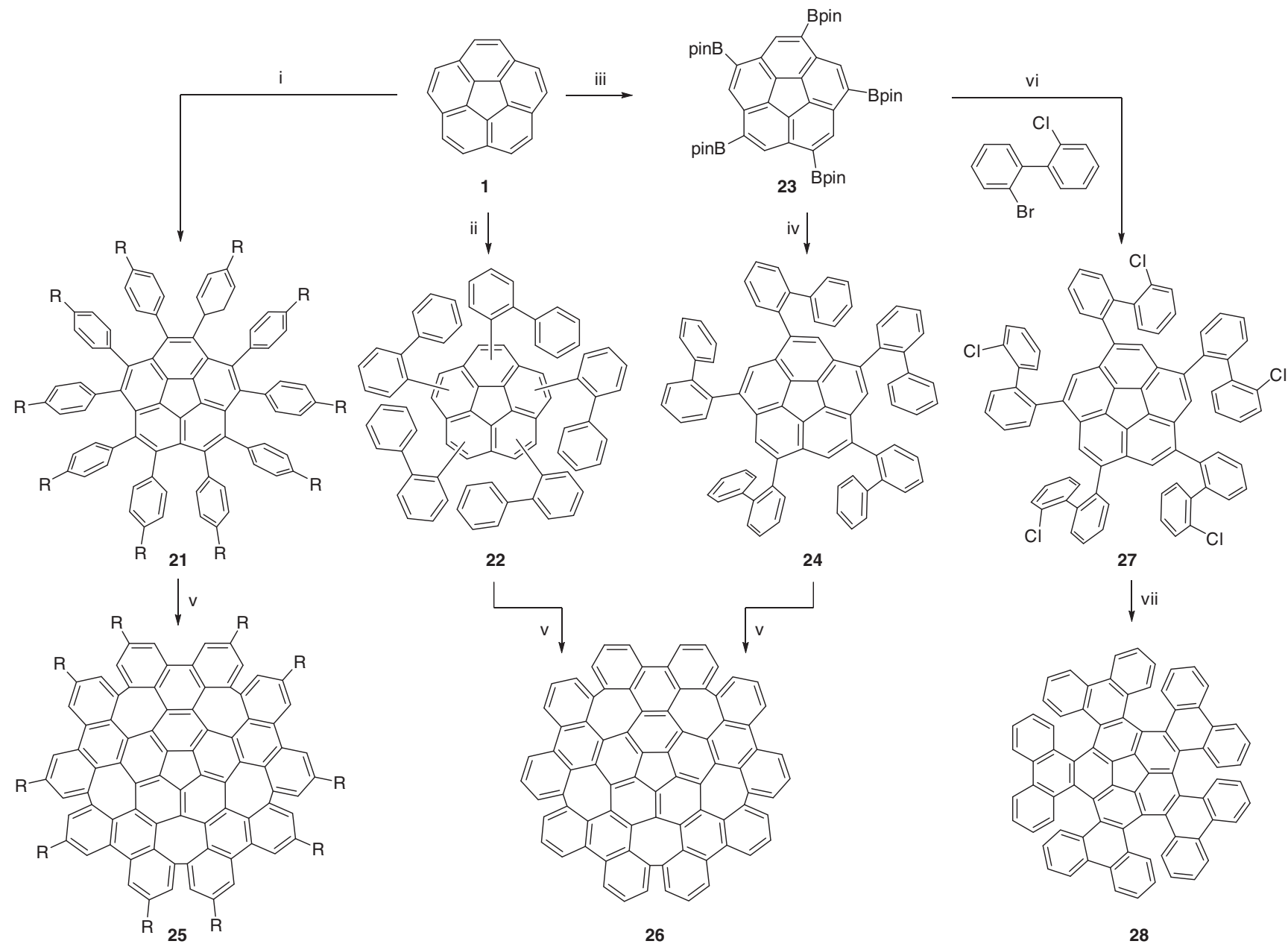

24

27

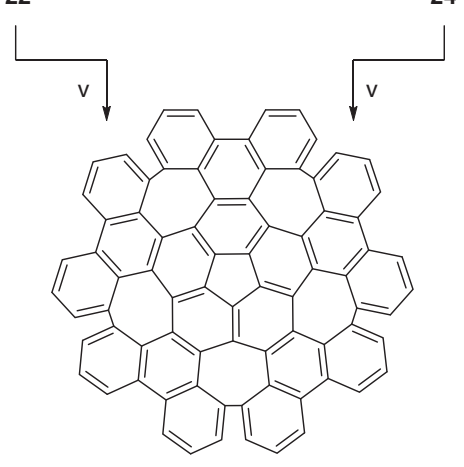

26

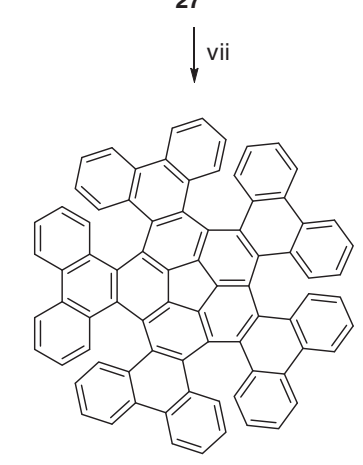

28

Fig. 3 Corannulene extension into warped nanographenes. (i) $\mathrm{Pd}(\mathrm{OAc})_{2}$, tris $\left(p\right.$-( $t$-butyl)phenyl)boroxine, 0 -chloranil, $\mathrm{DCE}, 80^{\circ} \mathrm{C}, 23 \%(\mathrm{R}=t$-butyl). (ii) $\mathrm{Pd}$ $(\mathrm{OAC})_{2}$, tris (o-biphenylyl)boroxin, o-chloroanil, DCE, $80^{\circ} \mathrm{C}, 16 \mathrm{~h}$; $21 \%$. (iii) (Ir (OMe)(cod)) $2, \mathrm{~B}_{2}$ (pin) $2,4,4^{\prime}$-dimethylbipyridyl, $t$-BuOK, THF, $85^{\circ} \mathrm{C}, 4$ days; 95\%. (iv) $\mathrm{Pd}_{2}(\mathrm{dba})_{3} \cdot \mathrm{CHCl}_{3}$, 2-bromobiphenyl, SPhos, $\mathrm{Cs}_{2} \mathrm{CO}_{3}$, toluene/water, $80{ }^{\circ} \mathrm{C}, 24 \mathrm{~h} ; 88 \%$. (v) DDQ, $\mathrm{TfOH} / \mathrm{CH}_{2} \mathrm{Cl} 2(5: 95), 0{ }^{\circ} \mathrm{C}, 30 \mathrm{~min} ; 50 \%$ (from 22), $40 \%$ (from 24). (vi) $\mathrm{Pd}_{2}(\mathrm{dba})_{3} \cdot \mathrm{CHCl}_{3}$, SPhos, $\mathrm{Cs}_{2} \mathrm{CO}_{3}$, toluene/water, $80^{\circ} \mathrm{C}, 24 \mathrm{~h} ; 76 \%$. (vii) $\mathrm{PdCl}_{2}\left(\mathrm{PCy}_{3}\right)_{2}, \mathrm{DBU}, \mathrm{DMAc}, 140{ }^{\circ} \mathrm{C}, 3 \mathrm{days} ; 10 \%$

analysed and the bowl structure is slightly deepened compared to corannulene but has a similar bowl-inversion barrier of approximately $11 \mathrm{kcal} / \mathrm{mol}$. The packing of extended 44 occurs in a highly ordered manner with unidirectional bowl-in-bowl columns with a distance of $15 \AA$ between bowls.

In 2016, Segawa and Itami presented a practically simple method to access thiophene-based extended aromatics in a general fashion (Fig. $4 \mathrm{~d}, \mathrm{e})^{37}$. In their synthesis, phenyleneethynylene derivatives $\mathbf{4 5}$ and $\mathbf{4 7}$ and elemental sulfur were combined to give thiophene-fused corannulenes $\mathbf{4 6}$ and $\mathbf{4 8}$. The yield for the mono-thienannulation was nearly quantitative and the synthesis is found to be practical and scalable.

Recently, Smith and Scott described the first palladiumcatalysed synthesis of tribenzocorannulene on a half-gram scale (Fig. $5 \mathrm{a})^{38}$. In this synthesis, the precursor 49 is obtained in three steps from commercially available compounds. Intramolecular arylation strategy is then used to fuse the aromatic scaffold and obtain 50 in an isolated yield of 56\%. The X-ray crystal structure of this molecule along with the computational data of other benzannulated corannulene structures helped in establishing that sequential benzannulation of the corannulene scaffold leads to a progressive decrease in the bowl depth.

A Pd-catalysed cascade developed by Würthner group in $2016^{39,40}$ was modified for the Suzuki-Miyaura cross-coupling of 51 and 52a $(X=B r)(\text { Fig. 5b })^{41}$. Boronic ester 51 was coupled with dicarboximide 52a to form 53 and 54. The competing intramolecular Suzuki-Miyaura coupling could be inhibited by substituting the dicarboximide with a chloro-bromo 52b $(\mathrm{X}=$ $\mathrm{Cl})$. Crystal structures of $\mathbf{5 3}$ exhibit columnar stacks with adjacent column alternating in the orientation of the curvature of corannulene. After optimising the conditions of the monoannulated 53, similar conditions of the Pd-catalysis together with the Heck additive, the diannulated bowl $\mathbf{5 7}$ with two bulky imide groups was formed from diboronic diester 55 and 56. The diboronic ester was isolated from the chromatographic purification of a mixture of regioisomers derived from altering equivalents of the diboron reagent. Unlike 53, the crystal arrangement of $\mathbf{5 7}$ displays two $\mathbf{5 7}$ molecules sandwiching two toluene solvate molecules. The sandwich molecules were positioned such that an imide substituent is placed towards the interior of the opposing corannulene fragment.

Baldridge and Siegel reported a trio of annulated corannulenes (Fig. 5c) ${ }^{42}$. 1,6-dibromo-2,5-dimethylcorannulene 58 is coupled with 2-fluoro-phenyl boronic acid and 2-chloro-phenyl boronic acid to give $59 \mathrm{a}(\mathrm{X}=\mathrm{Cl})$ and $59 \mathrm{~b}(\mathrm{X}=\mathrm{F})$ respectively. 59a was converted to 60 via a palladium-catalysed $\mathrm{C}-\mathrm{H}$ insertion with $\mathrm{Pd}$ $(\mathrm{OAc})_{2}$, it can also be converted to another indenoannulated $\mathbf{6 1}$ that forms through a $\mathrm{C}-\mathrm{C}$ coupling with $\mathrm{Pd}\left(\mathrm{PCy}_{3}\right)_{2} \mathrm{Cl}_{2}$. As for fluorinated 59b, reacting it with silyl cation with microwave heating gave a mixture of products 60-62. Packing behaviour of 


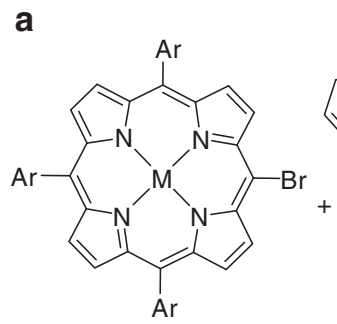

29<smiles>Brc1cccc2ccc3c4ccccc4c4ccc5c6ccccc6c6ccc1c2c6c5c34</smiles>

30

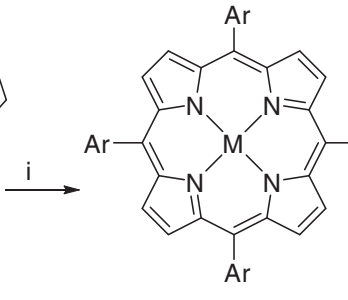

31<smiles>CC=C(C)C</smiles>

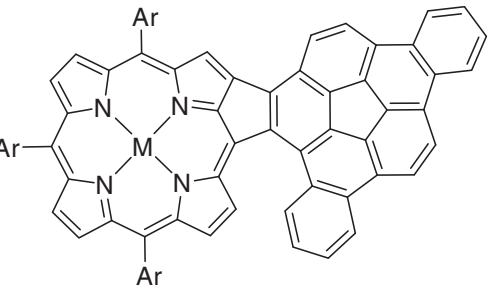

34

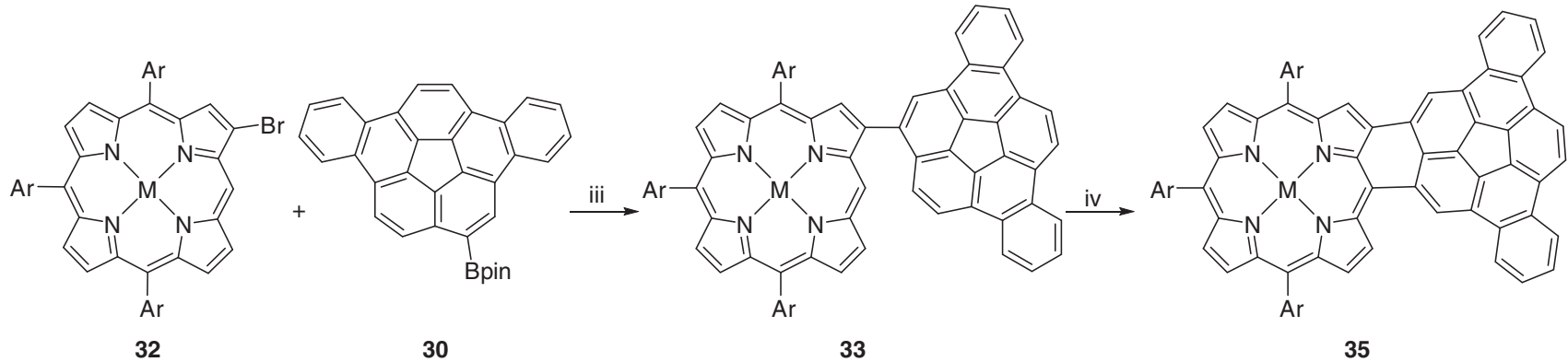

32

30

33

35

b

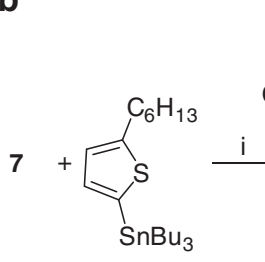

36

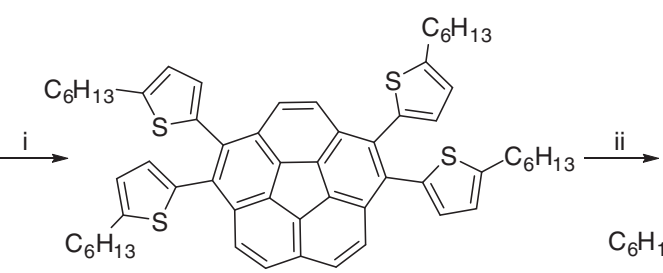

38

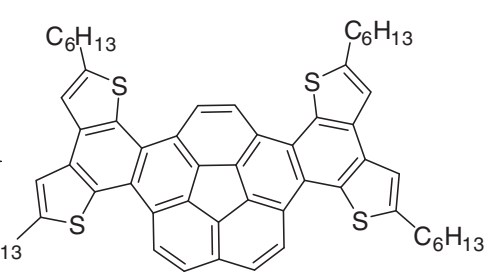

40
C<smiles>Brc1cc2ccc3ccc4ccc5ccc1c1c5c4c3c21</smiles><smiles>Cc1cc(C)cc(C#Cc2cc(C)cc(C)c2)c1</smiles><smiles>CC#CS1=C=C([15CH2]C(C)(C)C)C=C1CC</smiles>

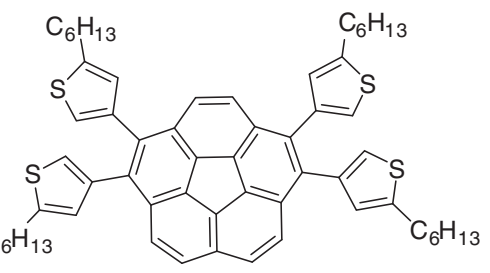

39

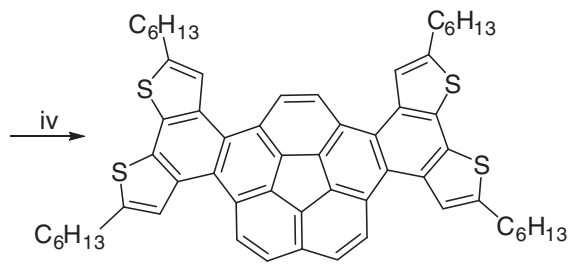

41

d

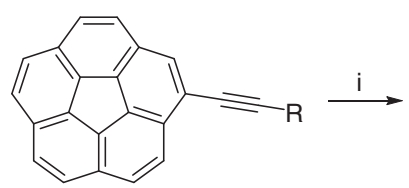

45

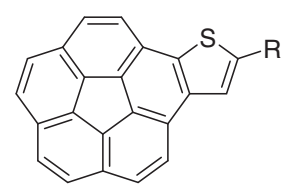

46 e<smiles>[Z17]c1cc2c([R])cc3c([R])cc4c([R])cc5c([R])cc1c1c5c4c3c21</smiles>

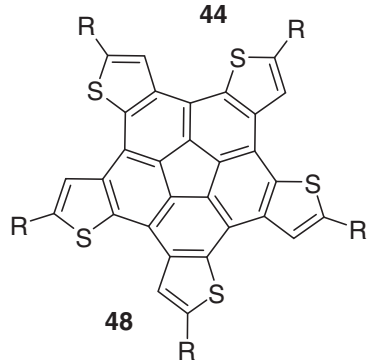

Fig. 4 Heteroatom inclusion in the extended corannulene scaffold. a Porphyrin-corannulene hybrids. (i) $\mathrm{Pd}$ cat., $\mathrm{K}_{3} \mathrm{PO} \mathrm{O}_{4}, \mathrm{THF} / \mathrm{H}_{2} \mathrm{O}, 40{ }^{\circ} \mathrm{C} ; 65 \%(\mathrm{M}=\mathrm{Zn})$, $75 \%\left(\mathrm{M}=\mathrm{Ni}\right.$ ). (ii) $\mathrm{FeCl}_{3}, \mathrm{CH}_{2} \mathrm{Cl}_{2} / \mathrm{MeNO}_{2}, \mathrm{rt}, 10-40 \mathrm{~min} ; 70 \%(\mathrm{M}=\mathrm{Zn}), 88 \%(\mathrm{M}=\mathrm{Ni})$. (iii) Pd cat., $\mathrm{K}_{3} \mathrm{PO}_{4}, \mathrm{THF} / \mathrm{H}_{2} \mathrm{O}, 40{ }^{\circ} \mathrm{C} ; 69 \%(\mathrm{M}=\mathrm{Zn}), 59 \%(\mathrm{M}=$ $\mathrm{Ni}$ ). (iv) $\mathrm{FeCl}_{3}, \mathrm{CH}_{2} \mathrm{Cl}_{2} / \mathrm{MeNO}_{2}, \mathrm{rt}, 10 \mathrm{~min} ; 45 \%(\mathrm{M}=\mathrm{Zn}), 29 \%(\mathrm{M}=\mathrm{Ni})$. b Thiophene-corannulene hybrids. (i) $\mathrm{Pd}\left(\mathrm{PPh}_{3}\right)_{2} \mathrm{Cl}_{2}, \mathrm{DMF}, 130{ }^{\circ} \mathrm{C}, 48 \mathrm{~h}, 95 \%$. (ii) $\mathrm{DDQ}, \mathrm{CH}_{3} \mathrm{SO}_{3} \mathrm{H}, \mathrm{DCM}, 0^{\circ} \mathrm{C}, 10 \mathrm{~min}, 60 \%$. (iii) $\mathrm{Pd}\left(\mathrm{PPh}_{3}\right)_{2} \mathrm{Cl}_{2}, \mathrm{DMF}, 130^{\circ} \mathrm{C}, 48 \mathrm{~h}, 82 \%$; (iv) $\mathrm{FeCl}_{3}, \mathrm{Et}_{2} \mathrm{O}, \mathrm{DCM}, \mathrm{rt}, 30 \mathrm{~min}, 27 \%$. c Synthesis of 44 . (i) $\mathrm{PdCl}_{2}$, DPPE, DBU, CsOPiv, dioxane, $110^{\circ} \mathrm{C}, 24 \mathrm{~h} ; 63 \%$. d Elemental sulfur for monothiophene-extended corannulene. (i) $\mathrm{S}_{8}, \mathrm{DMF}, 140{ }^{\circ} \mathrm{C}, 48 \mathrm{~h}(\mathrm{R}=4$-tertbutylphenyl). e Elemental sulfur for pentathiophene-extended corannulene. (i) $\mathrm{S}_{8}, \mathrm{DMF}, 140{ }^{\circ} \mathrm{C}, 48 \mathrm{~h}$ ( $\mathrm{R}=3,5$-di-tert-butylphenylacetylene)

the structures follow rough columns where symmetrical 60 and $\mathbf{6 1}$ follows a unidirectional form while racemic mixture of $\mathbf{6 2}$ exhibits a slip-stacked arrangement with enantiomeric columns following either direction.

In 2018, the preparation of nitrogen-containing benzocorannulenes were described (Fig. 6). Here, the synthesis starts with the oxidative dimerization of 9-aminophenanthrene $\mathbf{6 3}$ to tetrabenzocarbazole $64^{43-46}$. A single fusion of the aromatic scaffold through palladium-catalysed $\mathrm{C}-\mathrm{Cl} / \mathrm{C}-\mathrm{H}$ coupling reaction furnished 65. Bromination of the twisted $\mathbf{6 5}$ then yields a triply brominated compound 66. A double $\mathrm{C}-\mathrm{Br} / \mathrm{C}-\mathrm{H}$ coupling reaction then affords aza-buckybowl 67 . Under iridium-catalysed 
a<smiles>CC(C)(C)C(C)(C)C</smiles>

b<smiles></smiles>

51

52

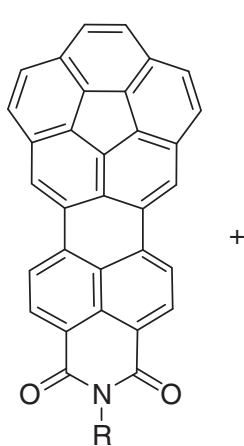

53

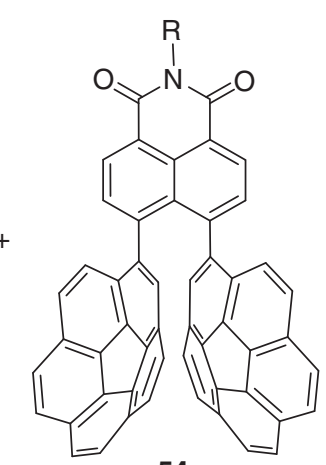

54

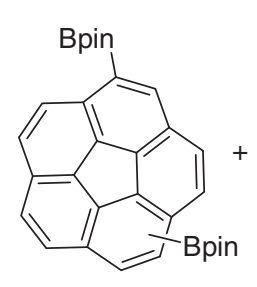

55<smiles>[R]N1C(=O)c2cccc3cccc(c23)C1=O</smiles>

56

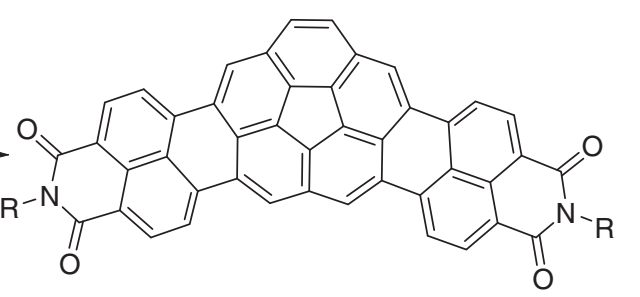

57

C

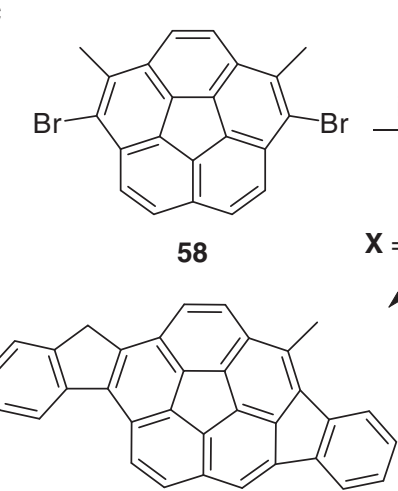

62<smiles></smiles>

$\mathbf{X}=\mathrm{Cl}$

59

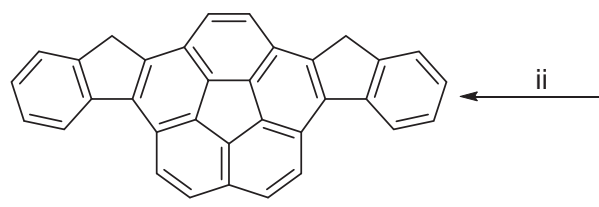

60

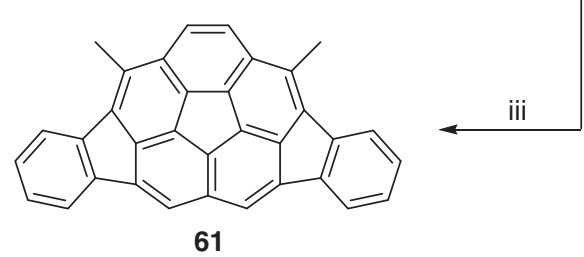

Fig. 5 Palladium-catalysed extension of the corannulene nucleus. a Synthesis of tribenzocorannulene. (i) $\mathrm{Pd}\left(\mathrm{PC} \mathrm{y}_{3}\right)_{2} \mathrm{Cl}_{2}, \mathrm{DBU}, \mathrm{DMAc}, 150{ }^{\circ} \mathrm{C}, 3$ days, $56 \%$. b Corannulene-diimide conjugates. (i) $\mathrm{Pd}_{2}(\mathrm{dba})_{3} . \mathrm{CHCl}_{3}, \mathrm{P}\left(\right.$ o-tolyl) ${ }_{3}, \mathrm{Cs}_{2} \mathrm{CO}_{3}, \mathrm{Bu}_{4} \mathrm{NCl}$, toluene/water (2:1), $90{ }^{\circ} \mathrm{C}, 12 \mathrm{~h}$; 15\% (53), 28\% (54). (ii) $\mathrm{Pd}$ ( $(\mathrm{dba})_{3}$. $\mathrm{CHCl}_{3}, \mathrm{P}\left(\mathrm{o}\right.$-tolyl) ${ }_{3}, \mathrm{Cs}_{2} \mathrm{CO}_{3}, \mathrm{H}_{2} \mathrm{O}, \mathrm{o}-\mathrm{DCB}, 90^{\circ} \mathrm{C}, 2 \mathrm{~h}$. (iii) $\mathrm{Bu}_{4} \mathrm{NCl}, 160^{\circ} \mathrm{C}, 24 \mathrm{~h}$ ( $\mathrm{R}=2,6$-diisopropylbenzene); $31 \%$. c Trio of five-membered ring-fusion with corannulene. (i) $\mathrm{Pd}\left(\mathrm{PPh}_{3}\right)_{4}$, (2-fluorophenyl)boronic acid, $\mathrm{K}_{2} \mathrm{CO}_{3}, \mathrm{THF}, \mathrm{H}_{2} \mathrm{O}, 70{ }^{\circ} \mathrm{C}, 15 \mathrm{~h}$; 80\%. (ii) $\mathrm{Pd}(\mathrm{OAc}$ ), [1,3-bis(2,6-diisopropylphenyl)-imidazolium chloride], $\mathrm{NMP}, \mathrm{K}_{2} \mathrm{CO}_{3}, 125^{\circ} \mathrm{C}, 20 \mathrm{~min} ; 32 \%$. (iii) $\mathrm{Pd}\left(\mathrm{PCy}_{3}\right)_{2} \mathrm{Cl}_{2}, \mathrm{DBU}, \mathrm{DMA}, 160{ }^{\circ} \mathrm{C}$ (microwave), $30 \mathrm{~min} ; 31 \%$. (iv) [ $\left.\mathrm{PPr}_{3} \mathrm{Si}\right]\left[\mathrm{CHB}_{11} \mathrm{H}_{5} \mathrm{Br}_{6}\right], \mathrm{DMDMS} \mathrm{PhCl}$, $120{ }^{\circ} \mathrm{C}$ (microwave), $30 \mathrm{~h} ; 6.2: 1: 4.5$ of $\mathbf{6 0}, \mathbf{6 1}$ and $\mathbf{6 2}$, respectively 


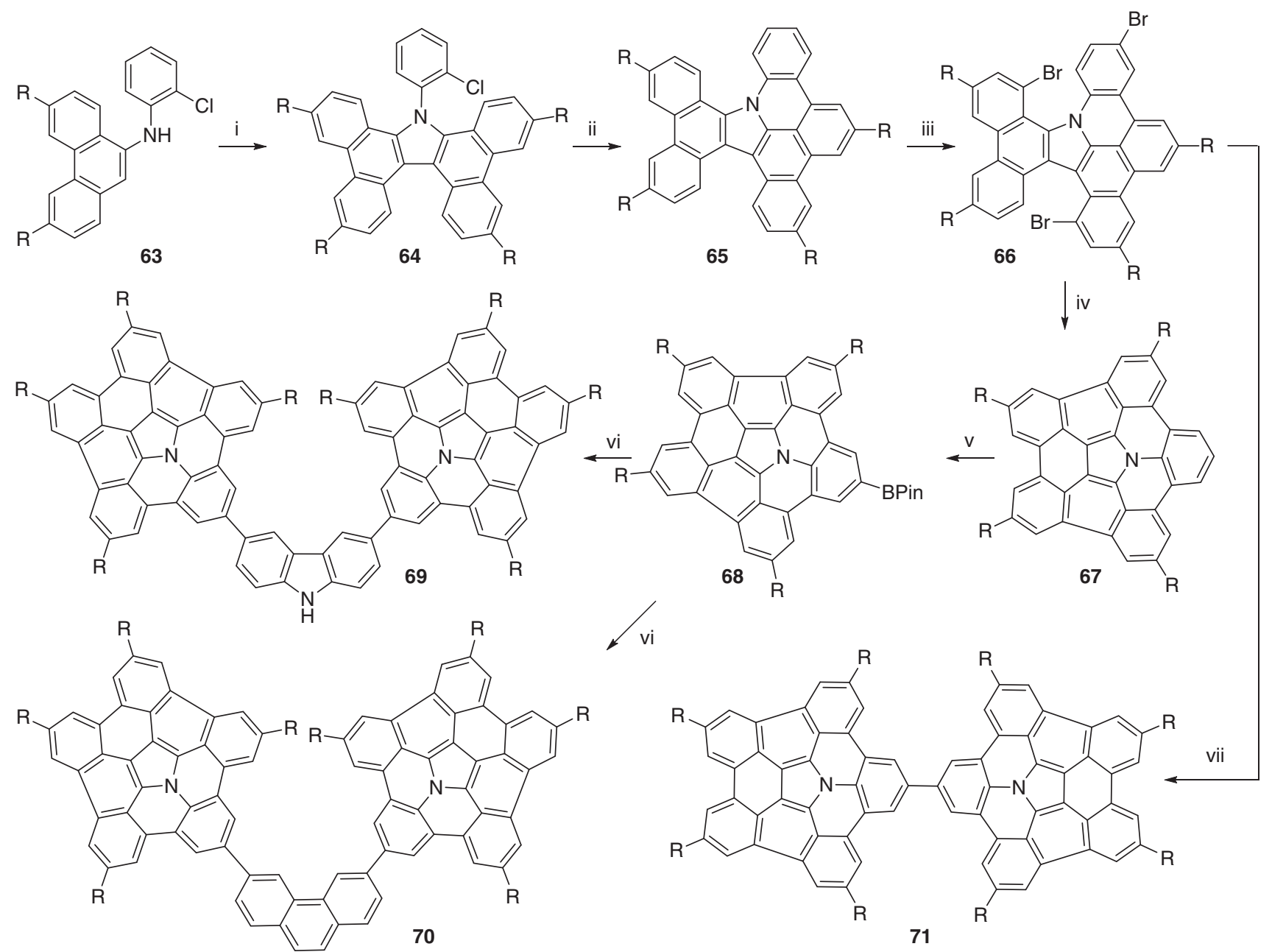

Fig. 6 Nitrogen-doped extended corannulenes. (i) 2,3-dichloro-5,6-dicyanobenzoquinone (DDQ), TFA, toluene, rt, $1 \mathrm{~h}, 94 \%$, $\left(R=t\right.$-butyl). (ii) $P d(O A c){ }_{2}$, $\mathrm{PCy}_{3}{ }^{*} \mathrm{HBF}_{4}, \mathrm{~K}_{2} \mathrm{CO}_{3}, \mathrm{DMA}, 130^{\circ} \mathrm{C}, 43 \mathrm{~h}, 63 \%$. (iii) $\mathrm{Br}_{2}, \mathrm{CCl}_{4}, 70{ }^{\circ} \mathrm{C}, 12.5 \mathrm{~h}, 56 \%$. (iv) $\mathrm{Pd}(\mathrm{OAc})_{2}, \mathrm{PCy}_{3}{ }^{*} \mathrm{HBF}_{4}, \mathrm{~K}_{2} \mathrm{CO}_{3}, \mathrm{DMA}, 130{ }^{\circ} \mathrm{C}, 16 \mathrm{~h}, 46 \%$. (v) bis (pinacolato)diboron, [lr(OMe)cod] $2,4,4^{\prime}$-di-tert-butyl- 2,2'-bipyridyl, octane, $10.5 \mathrm{~h}, 110{ }^{\circ} \mathrm{C}, 80 \%$. (vi) $\mathrm{Pd}\left(\mathrm{PPh}_{3}\right)_{4}, \mathrm{Cs}_{2} \mathrm{CO}_{3}, \mathrm{THF} / \mathrm{H}_{2} \mathrm{O}, \mathrm{reflux}, 4 \mathrm{~h}$ for 69 (50\%); $\mathrm{Pd}\left(\mathrm{PPh}_{3}\right)_{4}, \mathrm{Cs}_{2} \mathrm{CO}_{3}, 1,4$ - dioxane $/ \mathrm{H}_{2} \mathrm{O}, 80^{\circ} \mathrm{C}, 1 \mathrm{~h}$ for 70 (68\%). (vii) $\mathrm{Pd}(\mathrm{OAc})_{2}, \mathrm{HPCy}_{3}{ }^{\star} \mathrm{HBF}_{4}, \mathrm{~K}_{2} \mathrm{CO}_{3}, \mathrm{DMA}, 130{ }^{\circ} \mathrm{C}, 31 \%$

reaction, $\mathbf{6 7}$ allows for the installation of a pinacole ester moiety (68). This functional group can be used to dimerize the azabuckybowl with aromatic spacers such as carbazole (69) or phenanthrene (70). Alternatively, a directly linked dimer 71 can be formed through tri-brominated $\mathbf{6 6}$ again under palladium catalysis. All of these extended azacorannulene systems show the capability of strongly interacting with fullerenes and forming supramolecular complexes.

Rh-catalysed coupling. A group of indenocorannulenes with a variety of functional groups using a $[(2+2)+2]$ cycloaddition route was developed by Siegel's group in $2006^{47}$. Diyne 74 was prepared from 73 and dichlorinated corannulene derivative 72 via a modified version of a procedure reported by Nolan (Fig. 7a) ${ }^{48}$. The diyne is reacted with second alkyne 75 in another cycloaddition step mediated by a rhodium catalyst to afford indenocorannulene 76 . $\mathrm{R}^{1}$ and $\mathrm{R}^{2}$ groups on alkyne facilitate this step whereas aromatic substituents at $\mathrm{R}^{5}$ promote higher yields as compared to alkyl groups.

In 2015, Baldridge and Siegel used the rhodium-mediated reaction between $\mathbf{7 7}$ and $\mathbf{7 8}$ to yield tetraarylindenocorannulene $\mathbf{7 9}{ }^{49}$. The tetraaryl groups in $\mathbf{7 9}$ were then fused through silylcation-induced intramolecular Friedel-Crafts arylation ${ }^{50}$ also developed by the Siegel group and discussed below. A net result of this fusion was preparation of a corannulene-graphene hybrid structure linked through a five-membered cycle $\mathbf{8 0}$ (Fig. 7b).

\section{Friedel-Crafts reactions}

Overview. Siegel's group reported a Friedel-Crafts arylation of fluorinated arenes in 2011 assisted by silyl cations through a dehydrofluorination reaction (Fig. $7 c)^{50}$. A corannulene-based substrate $\mathbf{8 1}$ was shown to undergo an intramolecular aryl coupling catalysed by silyl cation ${ }^{i} \mathrm{Pr}_{3} \mathrm{Si}^{+}$through elimination of $\mathrm{HF}$ to form indenoannulated 82. Earlier examples of the synthesis of compounds 60, 61, 62 and 80 also utilised this method.

In 2018, Wu, Siegel and Chi described corannulene dimer diradicaloids via multi-step synthesis (Fig. 7d). The key step of connecting the corannulene scaffolds was achieved through intramolecular Friedel-Crafts alkylations on di-aldehyde substrates 83. Oxidative dehydrogenation with the help of DDQ provided the fully aromatic extended structures $\mathbf{8 4}^{51}$.

\section{Cycloaddition reactions}

Diels-Alder cycloaddition. Sygula's group in 2005 reported the synthesis of corannulyne $19^{52}$. 19 could be accessed through the ortho-deprotonation of bromocorannulene 42 in the presence of excess sodium amide and a catalytic amount of potassium tertbutoxide (Fig. 8a). 19 is highly valuable as it can take part in 
a

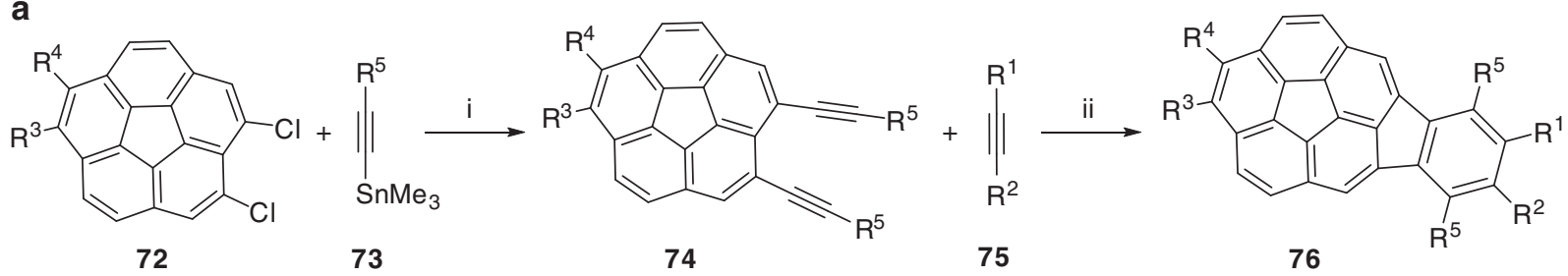

b<smiles>COC(=O)c1c(C(=O)OC)c2ccc3cc(C#Cc4ccccc4F)c4c(C#Cc5ccccc5F)cc5ccc1c2c3c54</smiles>

77

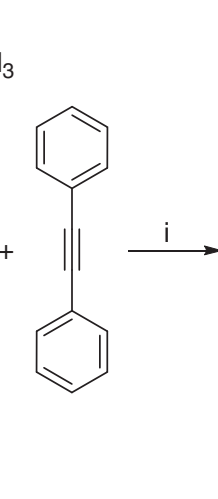

78

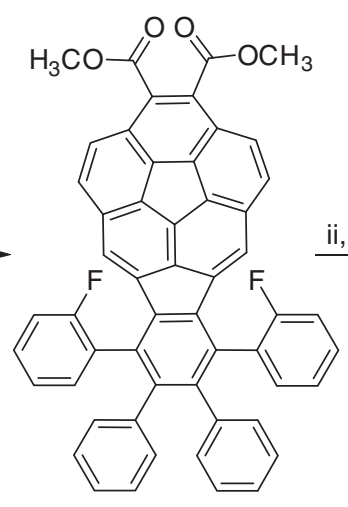

79

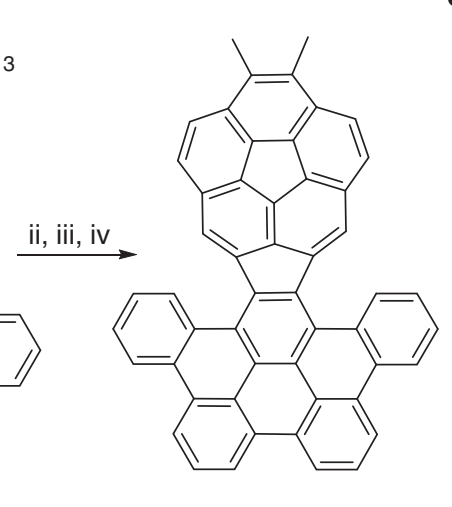

80
C

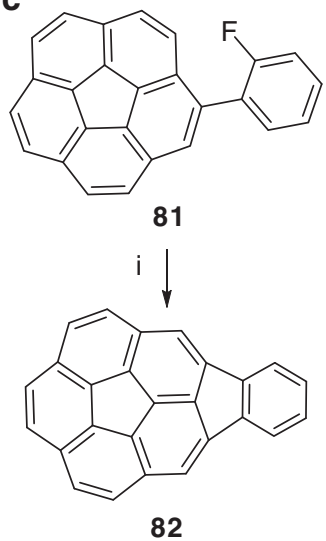

d

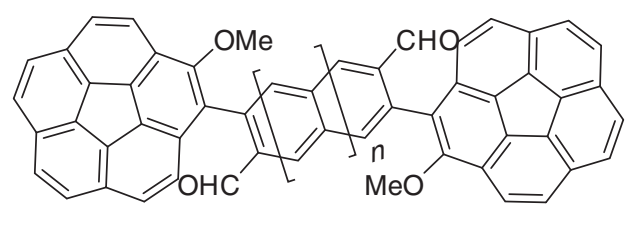

83

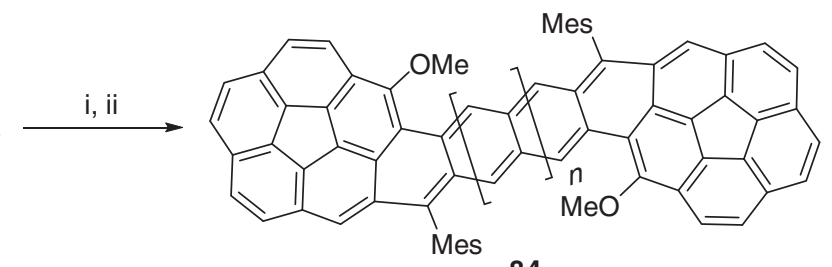

84

Fig. 7 Corannulene extension pathways involving rhodium catalysis and Friedel-Crafts reactions. a Synthesis of indenocorannulenes. (i) $\mathrm{Pd}(\mathrm{OAc})_{2}, \mathrm{IPr} \mathrm{HCl}$ $t$-BuOK, DME, $110{ }^{\circ} \mathrm{C}, 3$ days; (ii) $\mathrm{RhCl}\left(\mathrm{PPh}_{3}\right)_{3}, \mathrm{p}$-xylene, $130{ }^{\circ} \mathrm{C}, 60$ h. 76a: $\mathrm{R}^{1}=\mathrm{R}^{2}=\mathrm{R}^{5}=\mathrm{Ph}, \mathrm{R}^{3}=\mathrm{R}^{4}=\mathrm{H} ; 54 \%$ 76b: $\mathrm{R}^{1}=\mathrm{R}^{2}=\mathrm{Ph}, \mathrm{R}^{3}=\mathrm{R}^{4}=\mathrm{H}, \mathrm{R}^{5}=n \mathrm{Pr}$; 42\%. 76c: $R^{1}=R^{2}=R^{5}=P h, R^{3}=R^{4}=C_{2} M e ; 64 \%$. 76d: $R^{1}=R^{2}=R^{3}=R^{4}=C_{2} M e, R^{5}=P h ; 19 \% .76 e: R^{1}=R^{2}=n P r, R^{3}=R^{4}=C O_{2} M e, R^{5}=P h ;$ 57\%. 76f: $R^{1}=R^{2}=P h, R^{3}=R^{4}=C_{2} M e, R^{5}=n P r ; 47 \% .76 g: R^{1}=R^{2}=R^{3}=R^{5}=P h, R^{4}=C_{2} M e ; 81 \% .76 h: R^{1}=C M e_{2} O H, R^{2}=R^{3}=R^{4}=H, R^{5}=$ $\mathrm{Ph} ; 60 \%$. 76i: $\mathrm{R}^{1}=\mathrm{CH}(\mathrm{OEt})_{2}, \mathrm{R}^{2}=\mathrm{R}^{3}=\mathrm{R}^{4}=\mathrm{H}, \mathrm{R}^{5}=n \mathrm{Pr} ; 14 \%$. 76j: $\mathrm{R}^{1}=\mathrm{CO}_{2} \mathrm{Me}, \mathrm{R}^{2}=\mathrm{R}^{3}=\mathrm{R}^{4}=\mathrm{H}, \mathrm{R}^{5}=n \operatorname{Pr}$, traces. b Corannulene-graphene hybrid. (i) $\left[\left(\mathrm{Ph}_{3} \mathrm{P}\right)_{3} \mathrm{RhCl}\right], \mathrm{p}$-xylene, $130{ }^{\circ} \mathrm{C}, 3$ days; $65-73 \%$. (ii) DIBAL-H, dry toluene, $-78{ }^{\circ} \mathrm{C}, 1 \mathrm{~h}$. (iii) $\mathrm{Et}_{3} \mathrm{SiH}, \mathrm{TFA}, \mathrm{CH}_{2} \mathrm{Cl}_{2}, \mathrm{O}^{\circ} \mathrm{C}, 3 \mathrm{~h} ; 25 \%$ (over two steps). (iv) $\left[\mathrm{Pr}_{3} \mathrm{Si}\right]^{+}\left[\mathrm{CB}_{11} \mathrm{H}_{6} \mathrm{Cl}_{6}\right]^{-}, \mathrm{PhCl},(\mathrm{MeS})_{2} \mathrm{Si}\left(\mathrm{CH}_{3}\right)_{2}, 90^{\circ} \mathrm{C}(\mathrm{MW}), 1 \mathrm{~h} ; 40 \%$. c Friedel-Craft arylation. (i) ${ }^{i} \mathrm{Pr}_{3} \mathrm{Si}^{+}\left[\mathrm{CB}_{11} \mathrm{H}_{6} \mathrm{Cl}_{6}\right]^{-}, \mathrm{Me}_{2} \mathrm{Si}\left(\mathrm{Mes}_{2}, \mathrm{PhCl}, 110{ }^{\circ} \mathrm{C}, 8 \mathrm{~h}\right.$; 79\%. d Corannulene diradicaloids synthesis. (i) Mesitylmagnesium bromide, $\mathrm{BF}_{3} \cdot \mathrm{OEt}_{2}$, rt. (ii) $\mathrm{DDQ}$, Toluene, $80^{\circ} \mathrm{C}(n=0,1)$

cycloaddition reactions with various dienes to give Diels-Alder adducts that can finally be aromatised to give extended aromatics. In this initial study furan was used as a diene to give $\mathbf{8 5}$ which was later treated with $\mathrm{Fe}_{2}(\mathrm{CO})_{9}$ to cleave the oxygen bridge and to give benzocorannulene 90 in quantitative yields.

In 2006, the generation of isocorannulenofuran $\mathbf{8 6}$ from the elimination of ethylene in 85 was reported (Fig. 8a) ${ }^{53}$. Unlike isobenzofuran, $\mathbf{8 6}$ is stable enough to be isolated for a full characterisation study. In the synthetic aspect, 86 can carry out Diels-Alder reactions with 87-89 (Fig. 8b). Their corresponding hydrocarbons 93-95 (Fig. 8c) can be furnished by deoxygenation of the corresponding Diels-Alder adducts using $\mathrm{Fe}_{2}(\mathrm{CO})_{9}$ or a low-valent titanium catalyst. Despite the low solubilities of 94 and $95,{ }^{1} \mathrm{H}$ NMR spectra could be obtained with HRMS to confirm their structures with their expected molecular ions.

Bis-corannulene molecular tweezer $\mathrm{C}_{60} \mathrm{H}_{24}$ was synthesised in 2007 beginning with isocorannulenefuran 86 (Fig. 8c) ${ }^{54}$. A DielsAlder reaction of $\mathbf{8 6}$ and $\mathbf{9 0}$ gives syn and anti Diels-Alder adducts with a total yield of $92 \%$ with anti isomer being the major product. The endoxode bridges in the adducts can be removed with low-valent titanium to produce hydrocarbon buckycatcher 96. Dark red crystals of 96-fullerene complexes reveal the position of fullerene within the concavity of the corannulenes. The complexes form as well in solution in an NMR titration experiment. Isocorannulenofuran $\mathbf{8 6}$ was further used by Sygula to create better receptors of fullerenes ${ }^{55}$.

Recently, isocorannulenofuran $\mathbf{8 6}$ allowed for reaction with a bis-benzyne precursor 91 in a double Diels-Alder cycloaddition to syn and anti adducts ${ }^{56}$. The endoxode bridges were removed in the presence of trimethylsilyl chloride and sodium iodide to afford 97 in which an anthracene bridges the two terminal corannulenes (Fig. 8c).

In the context of Diels-Alder chemistry as illustrated by the work of Sygula, the Stuparu group showed that bis-corannulyne can be generated and trapped with furan while using tetrabromocorannulene as the precursor ${ }^{57}$.

1,3-Dipolar cycloaddition. Nozaki's group introduced 1,3-dipolar cycloaddition between azomethine ylide and corannulene as a viable synthetic method to access nitrogen-doped corannulenes 
a<smiles>Brc1cc2ccc3ccc4ccc5ccc1c1c5c4c3c21</smiles>

42<smiles>c1cc2ccc3ccc4ccc5ccc1c1c2c3c4c51</smiles>

19

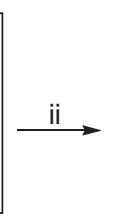

b<smiles>c1ccccc1</smiles>

87<smiles>c1ccc2ccccc2c1</smiles>

88<smiles>c1ccc2c(c#1)-c1ccccc1-2</smiles>

89<smiles></smiles>

85<smiles>C#C[C@H]1C=Cc2ccc3c4cocc4c4ccc5ccc1c2c5c4-3</smiles>

86

C<smiles>C1#Cc2ccccc2C#Cc2ccccc21</smiles>
90<smiles>CCCOc1cc(S(C)(=O)=O)c([O-])cc1O</smiles>
91<smiles></smiles><smiles></smiles>

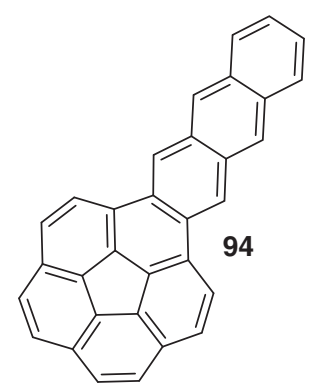

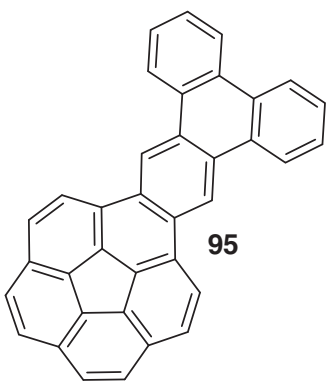

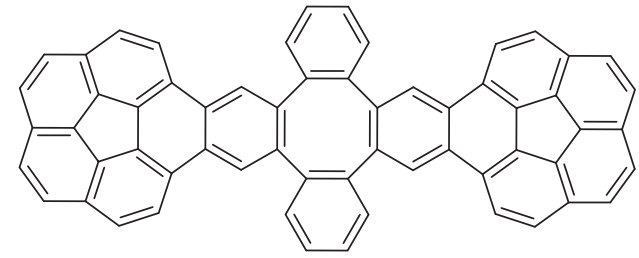

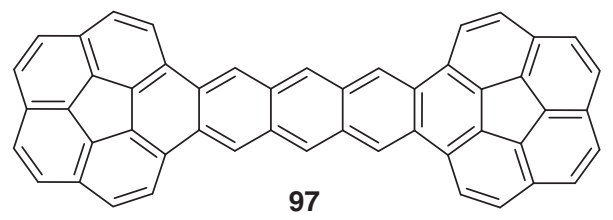

96

d

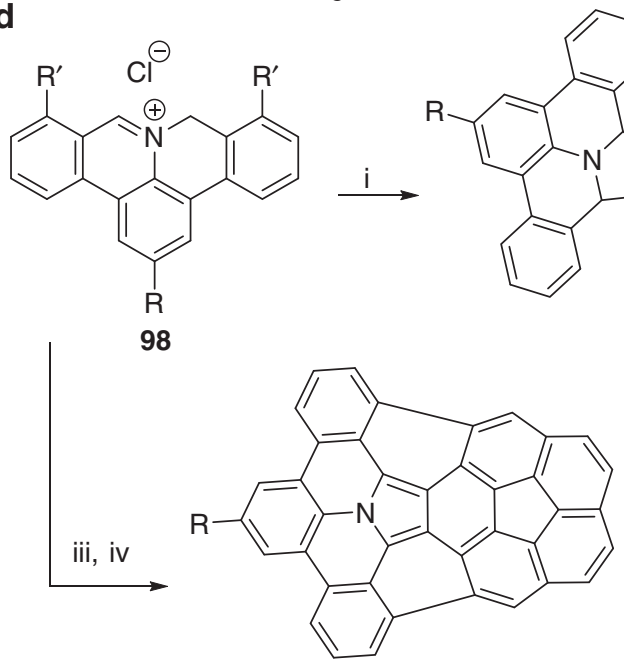

101

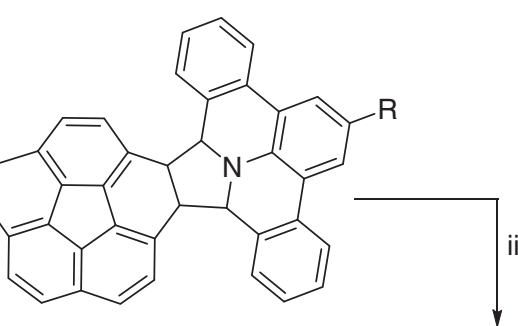

99

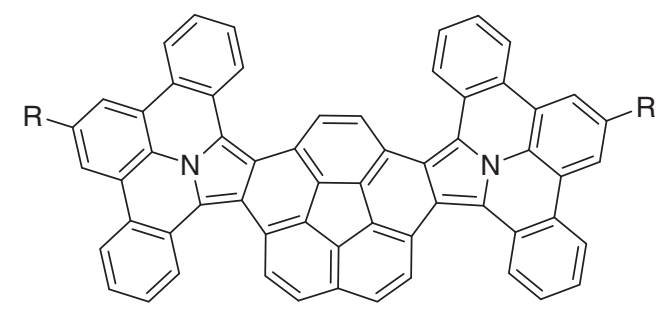

100

Fig. 8 Cycloaddition pathways for extension of corannulene. a Synthesis of corannulyne and isocorannulenofuran. (i) $\mathrm{NaNH}_{2}, t-\mathrm{BuOK} \mathrm{THF}$, rt. (ii) Furan (excess); 80\%. (iii) 2,6-bis-2-pyridyl-1,2,4,5-tetrazine, $\mathrm{CHCl}_{3}, 55^{\circ} \mathrm{C}, 15 \mathrm{~min} ; 94 \%$. b Various arynes useful in reaction with isocorannulenofuran. c Extended aromatic structures. d 1,3-Dipolar cycloaddition. (i) corannulene 1, $\mathrm{Pr}_{2} \mathrm{NEt}, \mathrm{DMSO}, 120^{\circ} \mathrm{C}, 1 \mathrm{~h} ; 29 \%$. (ii) $\mathrm{DDQ}, \mathrm{CH}_{2} \mathrm{Cl}{ }_{2}, \mathrm{rt}, 14 \mathrm{~h} ; 80 \%(\mathrm{R}=t-\mathrm{Bu}$, $\mathrm{R}^{\prime}=\mathrm{H}$ ). (iii) corannulene $\mathbf{1}, \mathrm{DMSO}, 140{ }^{\circ} \mathrm{C}, 2 \mathrm{~h}$; $\mathrm{DDQ}, \mathrm{rt}, 2 \mathrm{~h} ; 22 \%$. (iv) $\mathrm{Pd}(\mathrm{OAc})_{2}, 150{ }^{\circ} \mathrm{C}, 24 \mathrm{~h} ; 46 \%\left(\mathrm{R}=t-\mathrm{Bu}, \mathrm{R}^{\prime}=\mathrm{Cl}\right)$

(Fig. 8d) ${ }^{58-60}$. The synthesis begins with iminium chloride salt 98 which gives rise to the ylide in situ upon treatment with diisopropyl ethylamine at $120^{\circ} \mathrm{C}$ for a period of an hour. The cycloaddition between the ylide and corannulene occurs at the rim double bond and produces mono- and bis-adducts in 46 and $29 \%$ (99) yields, respectively. These adducts can be subjected to aromatisation through dehydrogenation reactions to give fully aromatic and extended corannulenes having nitrogen atom(s) in the scaffold (100). A subsequent study utilized bis-chloro-based salt that allows for an intramolecular cyclization to further stich the aromatic scaffold into a larger and highly curved aromatic system (101). 


\section{Photochemistry}

Photochemical pathway. The synthesis of corannulene carbaldehyde $\mathbf{1 0 2}$ at a $15 \mathrm{~g}$ scale and in an isolated yield of $>90 \%$ made it possible to explore its application in synthesis of corannulenebased vinylenes 103 through a Wittig olefination reaction with a variety of commercially available phosphonium ylides (Fig. 9a) ${ }^{61,62}$. In subsequent studies, these stilbene-like precursors were shown to undergo a photocyclisation-induced oxidation reaction to yield extended corannulenes $\mathbf{1 0 4}^{62,63}$. The modularity of this process was further demonstrated through switching of the coupling partners such that commercially available aldehydes were used and corannulene was transformed into a ylide compound. Lastly, corannulene ketone was also shown to be applicable in this synthetic scheme. Initial results show that the mild nature of the reaction allowed for the incorporation of reactive sites or heteroatoms in the final compounds. Recently, this method was used to combine benzo-pyrene $e^{64}$ or helicene $e^{65}$ with corannulene.

Wang, Siegel and Li recently accomplished synthesis of a highly complex and beautiful planar-non-planar hybrid structure named as 'corannurylene pentapetalae' (Fig. 9a) ${ }^{66}$. In their design, perylene diimide was used as the planar fragment and corannulene was used as the curved core. The perylene diimide chromophore is arranged around this core in a 5-fold symmetric fashion to give a flower-like molecule. The final step of the synthesis involved an oxidative photocyclization reaction of $\mathbf{1 0 5}$ to afford 106.

\section{Scholl reactions}

Overview. In 2018, Martín and coworkers presented an elegant molecular hybrid of coronene and corannulene ${ }^{67}$. The final step of the synthesis involved precursor $\mathbf{1 0 7}$ that upon treatment with $\mathrm{FeCl}_{3}$ formed 108 with a positively curved helical structure. All the ring closures here led to six-membered rings. Under different oxidative conditions (DDQ, TfOH), however, one more ring formed and it was composed of seven members. In this molecule (109) both curvatures could be observed in the crystal structure. 109 could also be obtained in a two-step process through 108 .

\section{Outlook}

Aromatic scaffold extension of corannulene is a viable synthetic route to access non-planar nanocarbons. This chemistry offers a

a

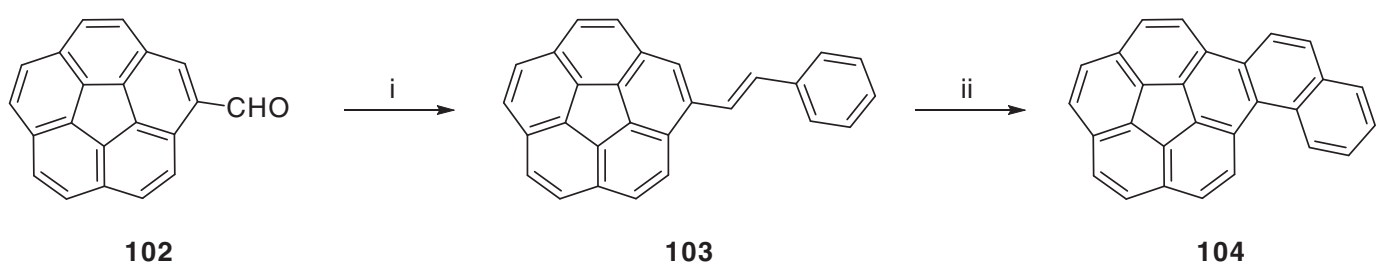

b<smiles>[R]c1cc2c([R])cc3c([R])cc4c([R])cc5c([R])cc1c1c5c4c3c21</smiles><smiles>[R7]N1C(=O)c2ccc3c4ccc5c6c(cc([Y9]([R])([H])[H])c(c7ccc(c2c37)C1=O)c64)C(=O)N([R7])C5=O</smiles>

105

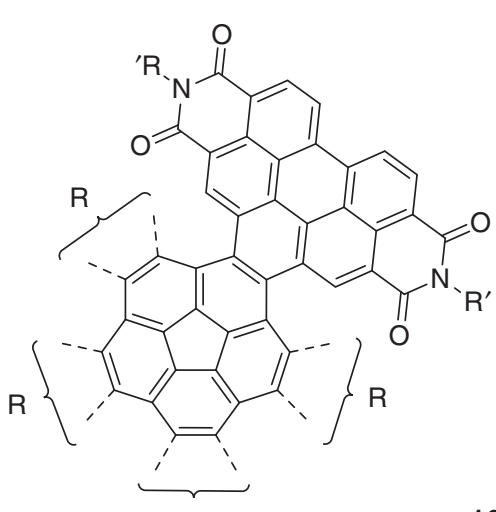

$\mathrm{R}$

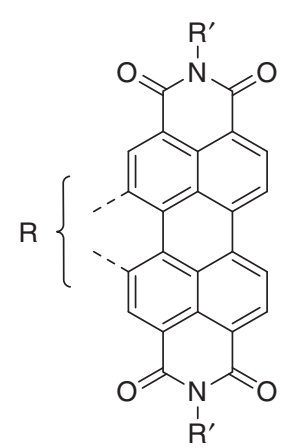

106
C<smiles></smiles>

107

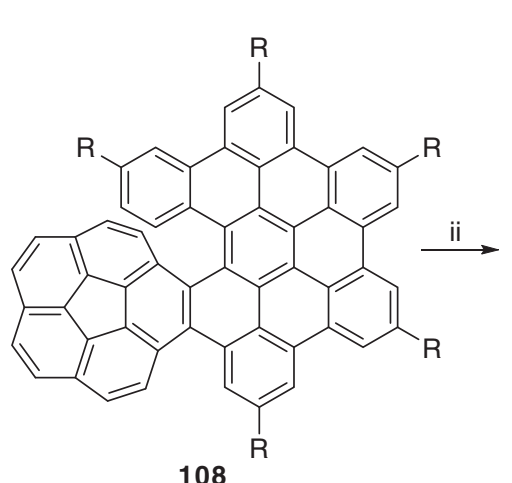

108

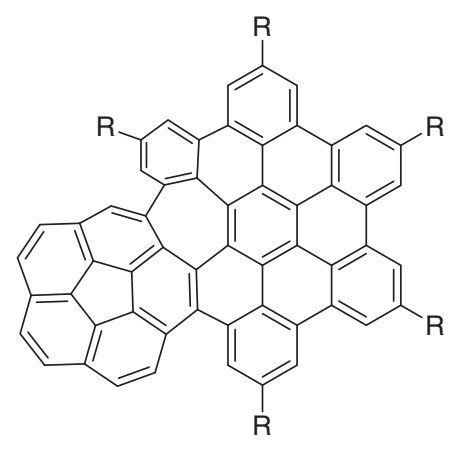

109 $\uparrow$ ii

Fig. 9 Light-induced and Scholl-based cyclisations for extension of corannulene. a Photochemical synthesis via stilbenes. (i) $\mathrm{RCH}_{3} \mathrm{PPh}{ }_{3}+\mathrm{Br}^{-}$, $n$-BuLi, $\mathrm{THF}$ (ii) $h v$, propylene oxide, $\mathrm{I}_{2}$, toluene (typically quantitative yields). b Corannurylene pentapetalae synthesis. (i) lodine, LED (40 W), toluene, $62 \%$ ( $\mathrm{R}^{\prime}=$ $\mathrm{C}_{11} \mathrm{H}_{23}$ ). c Corannulene-coronene hybrid synthesis. (i) $\mathrm{FeCl}_{3}, \mathrm{MeNO}_{2},-50{ }^{\circ} \mathrm{C}, 15 \mathrm{~min} 69 \%$. (ii) $\mathrm{DDQ}, \mathrm{TfOH}, 0{ }^{\circ} \mathrm{C}, 15 \mathrm{~min}, 48 \%$ (from 107 ), $100 \%$ (from 108) $(R=t-B u)$ 
synthetic challenge to those interested in the intrinsic beauty of the chemical structures and motivated to develop rational synthetic pathways. To others, new material properties arising from the non-planarity may be of significant attraction. It is interesting to note that to some five-membered rings represents defects in graphene and offers a completely different perspective to the importance of such curved structures. As such, the approach discussed here is not the only one to induce non-planarity into graphene-like structures. Larger seven or eight-membered rings can also achieve this goal ${ }^{6}$. Moreover, multiple five-membered rings as a core as shown by the elegant work of Chow and Kuck ${ }^{68}$ can be used to render the structure non-planar. However, continued improvement in access to large quantities of corannulene as well as its functionalized derivatives that serve as precursors to the extended structures makes this approach particularly appealing towards the synthesis of curved nanocarbons. Nonetheless, multistep nature of most of the current synthetic protocols with associated time-consuming chromatographic purifications and low-to-moderate overall yields all seem to restrict the appeal of this chemistry to experts. Therefore, one-pot procedures involving cascade or multicomponent reactions need to be considered and developed in the present context. Such efforts can be combined with the concept of mechanochemistry 69,70 . The motivation for exploring the applicability of such unconventional processes and their combination is not only to enhance practicality of non-planar nanocarbon synthesis but also to improve sustainability metrics of such endeavours.

Received: 26 January 2018 Accepted: 3 May 2019

Published online: 28 May 2019

\section{References}

1. Kroto, H. W., Heath, J. R., O’Brien, S. C., Curl, R. F. \& Smalley, R. E. C 60 : Buckminsterfullerene. Nature 318, 162-163 (1985).

2. Iijima, S. Helical microtubules of graphitic carbon. Nature 354, 56-58 (1991).

3. Novoselov, K. S. et al. Electric field effect in atomically thin carbon films. Science 306, 666-669 (2004).

4. Scott, L. T. et al. A rational chemical synthesis of $\mathrm{C}_{60}$. Science $295,1500-1503$ (2002).

5. Narita, A., Wang, X.-Y., Feng, X. \& Mullen, K. M. New advances in nanographene chemistry. Chem. Soc. Rev. 44, 6616-6643 (2015).

6. Márquez, I. R., Castro-Fernández, S., Millán, A. \& Campaña, A. G. Synthesis of distorted nanographenes containing seven- and eight-membered carbocycles. Chem. Commun. 54, 6705-6718 (2018).

7. Ball, M. et al. Contorted Polycyclic Aromatics. Acc. Chem. Res. 48, 267-276 (2015).

8. Majewski, M. A. \& Stępień, M. Bowls, Hoops, and Saddles: Synthetic Approaches to Curved Aromatic Molecules. Angew. Chem. Int. Ed. 58, 86-116 (2019).

9. Tsefrikas, V. M. \& Scott, L. T. Geodesic polyarenes by flash vacuum pyrolysis. Chem. Rev. 106, 4868-4884 (2006).

10. Wu, Y.-T. \& Siegel, J. S. Aromatic molecular-bowl hydrocarbons: synthetic derivatives, their structures, and physical properties. Chem. Rev. 106, 4843-4867 (2006).

11. Sygula, A. Chemistry on a half-shell: synthesis and derivatization of buckybowls. Eur. J. Org. Chem. 1611-1625 (2011).

12. Wu, Y.-T. \& Siegel, J. S. Synthesis, structures, and physical properties of aromatic molecular-bowl hydrocarbons. Top. Curr. Chem. 349, 63-120 (2014).

13. Nestoros, E. \& Stuparu, M. C. Corannulene: a molecular bowl of carbon with multifaceted properties and diverse applications. Chem. Commun. $\mathbf{5 4}$ 6503-6519 (2018).

14. Zabula, A. V., Spisak, S. N., Filatov, A. S., Rogachev, A. Y. \& Petrukhina, M. A. Record alkali metal intercalation by highly charged corannulene. Acc. Chem. Res. 51, 1541-1549 (2018).

15. Rice, A. M., Dolgopolova, E. A. \& Shustova, N. B. Fulleretic materials: buckyball- and buckybowl-based crystalline frameworks. Chem. Mater. 29, 7054-7061 (2017).
16. Sygula, A. Corannulene-adorned molecular receptors for fullerenes utilizing the $\pi-\pi$ stacking of curved-surface conjugated carbon networks. design, synthesis and testing. Synlett 27, 2070-2080 (2016).

17. Schmidt, B. M. \& Lentz, D. Syntheses and properties of buckybowls bearing electron-withdrawing groups. Chem. Lett. 43, 171-177 (2014).

18. Saito, M., Shinokubo, H. \& Sakurai, H. Figuration of bowl-shaped $\pi-$ conjugated molecules: properties and functions. Mater. Chem. Front. 2, 635-661 (2018).

19. Hou, X.-Q. et al. Bowl-shaped conjugated polycycles. Chin. Chem. Lett. 27, 1166-1174 (2016).

20. Haupt, A. \& Lentz, D. Corannulenes with electron-withdrawing substituents: synthetic approaches and resulting structural and electronic properties. Chem. Eur. J. 25, 3440-3454 (2019).

21. Barth, W. E. \& Lawton, R. G. Dibenzo[ghi,mno]fluoranthene. J. Am. Chem. Soc. 88, 380-381 (1966).

22. Scott, L. T., Hashemi, M. M., Meyer, D. T. \& Warren, H. B. Corannulene. a convenient new synthesis. J. Am. Chem. Soc. 113, 7082-7084 (1991).

23. Scott, L. T. et al. A short, rigid, structurally pure carbon nanotube by stepwise chemical synthesis. J. Am. Chem. Soc. 134, 107-110 (2012). First rational synthesis of carbon nanotube end-cap by aromatic area extension of corannulene.

24. Scott, L. T. Methods for the chemical synthesis of carbon nanotubes: an approach based on hemispherical polyarene templates. Pure Appl. Chem. 89, 4616-12 (2017).

25. Jackson, E. A., Steinberg, B. D., Bancu, M., Wakamiya, A. \& Scott, L. T. Pentaindenocorannulene and Tetraindenocorannulene: new aromatic hydrocarbon $\pi$ systems with curvatures surpassing that of $\mathrm{C}_{60}$. J. Am. Chem. Soc. 129, 484-485 (2007). Design of deeper corannulene bowls through aromatic extension with five-membered rings.

26. Steinberg, B. D. et al. Aromatic $\pi$-systems more curved than $\mathrm{C}_{60}$. The complete family of all indenocorannulenes synthesized by iterative microwave-assisted intramolecular arylations. J. Am. Chem. Soc. 131, 10537-10545 (2009)

27. Wu, T.-C., Hsin, H.-J., Kuo, M.-Y., Li, C.-H. \& Wu, Y.-T. Synthesis and structural analysis of a highly curved buckybowl containing corannulene and sumanene fragments. J. Am. Chem. Soc. 133, 16319-16321 (2011). Hybridization of non-planar corannulene and sumanene motifs into one structure.

28. Wu, T.-C., Chen, M.-K., Lee, Y.-W., Kuo, M.-Y. \& Wu, Y.-T. Bowl-shaped fragments of $\mathrm{C}_{70}$ or higher fullerenes: synthesis, structural analysis, and inversion dynamics. Angew. Chem. Int. Ed. 52, 1289-1293 (2012).

29. Yanney, M., Fronczek, F. R., Henry, W. P., Beard, D. J. \& Sygula, A. Cyclotrimerization of corannulyne: steric hindrance tunes the inversion barriers of corannulene bowls. Eur. J. Org. Chem. 2011, 6636-6639 (2011).

30. Kawasumi, K., Zhang, Q., Segawa, Y., Scott, L. T. \& Itami, K. A grossly warped nanographene and the consequences of multiple odd-membered-ring defects. Nat. Chem. 5, 739-744 (2013). First synthesis of a nano-graphene based on the corannulene core.

31. Eliseeva, M. N. \& Scott, L. T. Pushing the Ir-catalyzed C-H polyborylation of aromatic compounds to maximum capacity by exploiting reversibility. J. Am. Chem. Soc. 134, 15169-15172 (2012).

32. Kato, K., Segawa, Y., Scott, L. T. \& Itami, K. A Quintuple [6]helicene with a corannulene core as a $\mathrm{C}_{5}$-symmetric propeller-shaped $\pi$-system. Angew. Chem. Int. Ed. 57, 1337-1341 (2018).

33. Lin, H.-A., Kato, K., Segawa, Y., Scott, L. T. \& Itami, K. Synthesis and structural features of thiophene-fused analogues of warped nanographene and quintuple helicene. Chem. Sci. 10, 2326-2330 (2019).

34. Ota, K., Tanaka, T. \& Osuka, A. meso- $\beta$ Dibenzo[a,g]corannulene-fused porphyrins. Org. Lett. 16, 2974-2977 (2014).

35. Lu, R.-Q. et al. Thiophene-fused bowl-shaped polycyclic aromatics with a dibenzo[a,g]corannulene core for organic field-effect transistors. Chem. Commun. 51, 1681-1684 (2015).

36. Lee, C.-W., Liu, E.-C. \& Wu, Y.-T. Palladium-catalyzed reaction of haloarenes with diarylethynes: synthesis, structural analysis, and properties of methylenebridged arenes. J. Org. Chem. 80, 10446-10456 (2015).

37. Meng, L., Fujikawa, T., Kuwayama, M., Segawa, Y. \& Itami, K. ThiopheneFused $\pi$-Systems from Diarylacetylenes and Elemental Sulfur. J. Am. Chem. Soc. 138, 10351-10355 (2016). Application of readily available alkyne derivatives of corannulene and elemental sufur to access thiophene-based extended buckybowls.

38. Smith, N. J. \& Scott, L. T. A practical synthesis and X-ray crystal structure of tribenzo[a, d, j]corannulene. Can. J. Chem. 95, 410-414 (2017).

39. Seifert, S., Schmidt, D. \& Würthner, F. A cross-coupling-annulation cascade from peri-dibromonaphthalimide to pseudo-rylene bisimides. Org. Chem. Front. 3, 1435-1442 (2016).

40. Seifert, S., Shoyama, K., Schmidt, D. \& Würthner, F. An electron-poor C-64 nanographene by palladium-catalyzed cascade C-C bond formation: one-pot 
synthesis and single-crystal structure analysis. Angew. Chem. Int. Ed. 55, 6390-6395 (2016).

41. Shoyama, K., Schmidt, D., Mahl, M. \& Würthner, F. Electron-poor bowlshaped polycyclic aromatic dicarboximides: synthesis, crystal structures, and optical and redox properties. Org. Lett. 19, 5328-5331 (2017).

42. Liu, S. et al. 1,2,3- versus 1,2-indeno ring fusions influence structure property and chirality of corannulene bowls. J. Org. Chem. 83, 3979-3986 (2018).

43. Yokoi, $\mathrm{H}$. et al. Nitrogen-embedded buckybowl and its assembly with $\mathrm{C}_{60}$. Nat. Commun. 6, 8215 (2015).

44. Takeda, M. et al. Azabuckybowl-based molecular tweezers as $\mathrm{C}_{60}$ and $\mathrm{C}_{70}$ receptors. J. Am. Chem. Soc. 140, 6336-6342 (2018).

45. Yokoi, H., Hiroto, S., Sakamaki, D., Seki, S. \& Shinokubo, H. Supramolecular assemblies of a nitrogen-embedded buckybowl dimer with $\mathrm{C}_{60}$. Chem. Sci. 9 , 819-824 (2018).

46. Yokoi, H., Hiroto, S. \& Shinokubo, H. Reversible $\sigma$-bond formation in bowlshaped $\pi$-radical cations: the effects of curved and planar structures. J. Am. Chem. Soc. 140, 4649-4655 (2018).

47. Wu, Y.-T., Hayama, T., Baldridge, K. K., Linden, A. \& Siegel, J. S. Synthesis of fluoranthenes and indenocorannulenes: elucidation of chiral stereoisomers on the basis of static molecular bowls. J. Am. Chem. Soc. 128, 6870-6884 (2006).

48. Grasa, G. A. \& Nolan, S. P. Palladium/imidazolium salt catalyzed coupling of aryl halides with hypervalent organostannates. Org. Lett. 3, 119-122 (2001).

49. Dutta, A. K., Linden, A., Zoppi, L., Baldridge, K. K. \& Siegel, J. S. Extended corannulenes: aromatic bowl/sheet hybridization. Angew. Chem. Int. Ed. Engl. 54, 10792-10796 (2015). First report on corannulene-graphene hybrid structure.

50. Allemann, O., Duttwyler, S., Romanato, P., Baldridge, K. K. \& Siegel, J. S. Proton-catalyzed, silane-fueled friedel-crafts coupling of fluoroarenes. Science 332, 574-577 (2011). Application of fluorinated precursors in aromatic area extension of corannulene.

51. Wang, Q. et al. Curved $\pi$-conjugated corannulene dimer diradicaloids. Chem. Sci. 9, 5100-5105 (2018).

52. Sygula, A., Sygula, R. \& Rabideau, P. W. The first buckybowl aryne. Corannulyne: a nonplanar benzyne. Org. Lett. 7, 4999-5001 (2005). First synthesis of a corannulene-based aryne with a wide applicability in DielsAlder pathway to extended structures.

53. Sygula, A., Sygula, R. \& Rabideau, P. W. Isocorannulenofuran: a versatile building block for the synthesis of large buckybowls. Org. Lett. 8, 5909-5911 (2006).

54. Sygula, A., Fronczek, F. R., Sygula, R., Rabideau, P. W. \& Olmstead, M. M. A double concave hydrocarbon buckycatcher. J. Am. Chem. Soc. 129, 3842-3843 (2007).

55. Abeyratne Kuragama, P. L., Fronczek, F. R. \& Sygula, A. Bis-corannulene Receptors for fullerenes based on klärner's tethers: reaching the affinity limits. Org. Lett. 17, 5292-5295 (2015).

56. Kumarasinghe, K. G. U. R., Fronczek, F. R., Valle, H. U. \& Sygula, A. Biscorannulenoanthracene: an angularly fused pentacene as a precursor for barrelene-tethered receptors for fullerenes. Org. Lett. 18, 3054-3057 (2016).

57. Furrer, F., Linden, A. \& Stuparu, M. C. Towards molecular ribbons of corannulene. Chem. Eur. J. 19, 13199-13206 (2013).

58. Tokimaru, Y., Ito, S. \& Nozaki, K. Benzene-fused azacorannulene bearing an internal nitrogen atom. Angew. Chem. Int. Ed. 54, 7256-7260 (2015). First report on incorporation of nitrogen atom into the central five-membered ring of a corannulene derivative.

59. Tokimaru, Y., Ito, S. \& Nozaki, K. Synthesis of pyrrole-fused corannulenes: 1,3-dipolar cycloaddition of azomethine ylides to corannulene. Angew. Chem. Int. Ed. 56, 15560-15564 (2017).

60. Tokimaru, Y., Ito, S. \& Nozaki, K. A hybrid of corannulene and azacorannulene: synthesis of a highly curved nitrogen-containing buckybowl. Angew. Chem. Int. Ed. 57, 9818-9822 (2018).

61. Rajeshkumar, V., Lee, Y. T. \& Stuparu, M. C. Corannulenecarbaldehyde: highyielding synthesis by rieche formylation and facile access to a variety of corannulene derivatives. Eur. J. Org. Chem. 36-40 (2016).
62. Rajeshkumar, V. \& Stuparu, M. C. A photochemical approach to aromatic extension of the corannulene nucleus. Chem. Commun. 52, 9957-9960 (2016). Demonstration that corannulene-based aldehyde and ylide building blocks can be combined in a highly practical manner to yield extended structures through a photochemical pathway.

63. Halilovic, D. et al. Photochemical synthesis and electronic properties of extended corannulenes with variable fluorination pattern. J. Org. Chem. 83, 3529-3536 (2018).

64. Rajeshkumar, V., Courté, M., Fichou, D. \& Stuparu, M. C. Synthesis and properties of large polycyclic aromatic hydrocarbons with planar and non-planar structural motifs. Eur. J. Org. Chem. 2016, 6010-6014 (2016).

65. Fujikawa, T., Preda, D. V., Segawa, Y., Itami, K. \& Scott, L. T. Corannulene-helicene hybrids: chiral $\pi$-systems comprising both bowl and helical motifs. Org. Lett. 18, 3992-3995 (2016).

66. Meng, D. et al. Corannurylene pentapetalae. J. Am. Chem. Soc. 141, 5402-5408 (2019).

67. Fernández-García, J. M. et al. J. Am. Chem. Soc. 140, 17188-17196 (2018).

68. Ip, H.-W., Ng, C.-F., Chow, H.-F. \& Kuck, D. Three-fold scholl-type cycloheptatriene ring formation around a tribenzotriquinacene core: toward warped graphenes. J. Am. Chem. Soc. 138, 13778-13781 (2016).

69. Howard, J. L., C., Qun \& Browne, D. L. Mechanochemistry as an emerging tool for molecular synthesis: what can it offer? Chem. Sci $\mathbf{9}$, 3080-3094 (2018)

70. Tan, D., Garcia, F. Main group mechanochemistry: from curiosity to established protocols. Chem. Soc. Rev. https://doi.org/10.1039/C7CS00813A (2019).

\section{Acknowledgements}

Financial support from the Ministry of Education Singapore under the AcRF Tier 1 (MOE2017-T1-001-17, M4011792) (2018-T1-001-176, M4012047); Agency for Science, Technology and Research (A*STAR)-AME IRG A1883c0006; and NTU (M4081566) is gratefully acknowledged.

\section{Author contributions}

E.M.M, D.H. and M.C.S. discussed pertinent literature examples, composed the text, and reviewed the manuscript. E.M.M. and D.H. contributed equally to this manuscript.

\section{Additional information}

Competing interests: The authors declare no competing interests.

Reprints and permission information is available online at http://npg.nature.com/ reprintsandpermissions/

Publisher's note: Springer Nature remains neutral with regard to jurisdictional claims in published maps and institutional affiliations.

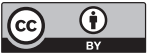

Open Access This article is licensed under a Creative Commons Attribution 4.0 International License, which permits use, sharing, adaptation, distribution and reproduction in any medium or format, as long as you give appropriate credit to the original author(s) and the source, provide a link to the Creative Commons license, and indicate if changes were made. The images or other third party material in this article are included in the article's Creative Commons license, unless indicated otherwise in a credit line to the material. If material is not included in the article's Creative Commons license and your intended use is not permitted by statutory regulation or exceeds the permitted use, you will need to obtain permission directly from the copyright holder. To view a copy of this license, visit http://creativecommons.org/ licenses/by/4.0/.

(C) The Author(s) 2019 